\title{
Selective Catalytic Reduction of NOx over V2O5-WO3-TiO2 SCR Catalysts-A Study at Elevated Pressure for Maritime Pre-turbine SCR Configuration
}

Christensen, Steen R.; Hansen, Brian B.; Pedersen, Kim H.; Thøgersen, Joakim R.; Jensen, Anker D.

Published in:

Emission Control Science and Technology

Link to article, DOI:

10.1007/s40825-019-00127-0

Publication date:

2019

Document Version

Peer reviewed version

Link back to DTU Orbit

Citation (APA):

Christensen, S. R., Hansen, B. B., Pedersen, K. H., Thøgersen, J. R., \& Jensen, A. D. (2019). Selective Catalytic Reduction of $\mathrm{NO}_{\text {over }} \mathrm{V}_{2} \mathrm{O}_{5}-\mathrm{WO}_{3}-\mathrm{TiO}_{2} \mathrm{SCR}$ Catalysts-A Study at Elevated Pressure for Maritime Pre-turbine SCR Configurâtion. Erhission ControlScience and Technology, 5(3), 263-278. https://doi.org/10.1007/s40825-019-00127-0

\section{General rights}

Copyright and moral rights for the publications made accessible in the public portal are retained by the authors and/or other copyright owners and it is a condition of accessing publications that users recognise and abide by the legal requirements associated with these rights.

- Users may download and print one copy of any publication from the public portal for the purpose of private study or research.

- You may not further distribute the material or use it for any profit-making activity or commercial gain

- You may freely distribute the URL identifying the publication in the public portal 


\title{
Selective Catalytic Reduction of $\mathrm{NO}_{x}$ over $\mathrm{V}_{2} \mathrm{O}_{5-}$ $\mathrm{WO}_{3}-\mathrm{TiO}_{2}$ SCR Catalysts - A Study at Elevated Pressure for Maritime Pre-turbine SCR Configuration
}

Steen R. Christensen ${ }^{a}$ (ORCID 0000-0002-1684-6321), Brian B. Hansen ${ }^{a}$ (ORCID 0000-00025829-9223), Kim H. Pedersen ${ }^{b}$, Joakim R. Thøgersen ${ }^{b}$, Anker D. Jensen ${ }^{a}{ }^{*}$

${ }^{a}$ Department of Chemical and Biochemical Engineering, Technical University of Denmark, Søltofts Plads B229, 2800 Kgs Lyngby, Denmark

${ }^{b}$ Umicore Denmark ApS, Nøjsomhedsvej 20, DK-2800 Kgs. Lyngby, Denmark

*Corresponding author: aj@kt.dtu.dk +45 45252841 ORCID 0000-0002-7341-4859

\begin{abstract}
The selective catalytic reduction ( $\mathrm{SCR}$ ) of $\mathrm{NO}_{x}$ using $\mathrm{NH}_{3}$, was studied at pressures up to 5 bar over a vanadium-based SCR catalyst $\left(\sim 1 \mathrm{wt} \% \mathrm{~V}_{2} \mathrm{O}_{5}\right.$ and $\left.10 \mathrm{wt} \% \mathrm{WO}_{3} / \mathrm{TiO}_{2}\right)$, relevant for the installation of SCR reactors upstream of the turbocharger at marine engines. Experiments were performed using both granulated catalyst in a lab scale fixed bed reactor and a monolith catalyst in a benchscale setup. The residence time across the catalytic bed was kept constant, by increasing the (normalized $\left(0^{\circ} \mathrm{C}, 1 \mathrm{~atm}\right)$ ) volumetric flow rate proportionally to the pressure. The results show that for the granulated catalyst, the $\mathrm{NO}_{x}$ conversion was independent of the pressure, indicating that the SCR kinetics are not affected by the increased pressure up to 5 bar. $\mathrm{NH}_{3}$ temperature programmed desorption experiments showed that the catalyst $\mathrm{NH}_{3}$ adsorption increased with more than 30\% when the pressure was increased from 1 bar to 4.5 bar. On the other hand, when the adsorption temperature was increased from $150^{\circ} \mathrm{C}$ to $300^{\circ} \mathrm{C}$ the adsorption capacity decreased by approximately $60 \%$ independent on the pressure. The SCR reaction was unaffected by the increased $\mathrm{NH}_{3}$ uptake caused by the increased pressure, because only a certain fraction of the sites $\left(\theta_{N H 3}^{*}=0.14\right)$ are active in the SCR reaction, and these are filled up at lower $\mathrm{NH}_{3}$ partial pressure than the total number of sites. Experiments using the monolithic catalyst showed that at temperatures above $250^{\circ} \mathrm{C}$ the $\mathrm{NO}_{\mathrm{x}}$ conversion was lower at an increased pressure (3.1 bar) due to increased internal and external diffusion limitations at the elevated pressure.
\end{abstract}

Keywords

Pre-turbo SCR; SCR of $\mathrm{NO}_{x}$ on Ships; High pressure SCR of $\mathrm{NO}_{x} ; \mathrm{NH}_{3} \mathrm{TPD} ; \mathrm{V} / \mathrm{W} / \mathrm{Ti}$ Catalyst; 


\section{Introduction}

Currently, more than $80 \%$ of the international transport of goods is covered by ships[1,2], and the majority of these (>90\%[3]), are powered by diesel engines. The diesel engine benefits from low emissions of $\mathrm{CO}_{2}(\mathrm{~g} / \mathrm{km})$, however, pollutants causing acidification and smog such as $\mathrm{SO}_{\times}\left(\mathrm{SO}_{2}, \mathrm{SO}_{3}\right.$, and $\left.\mathrm{H}_{2} \mathrm{SO}_{4}\right)$ and $\mathrm{NO}_{x}\left(\mathrm{NO}\right.$ and $\left.\mathrm{NO}_{2}\right)$ are produced[4-8]. It has been estimated that approximately $30 \%$ of the global anthropogenic $\mathrm{NO}_{\mathrm{x}}$ emissions originate from the overall transport sector, and 5-15\% from the marine industry alone $[4,9]$. The emissions of $\mathrm{NO}_{x}$ and $\mathrm{SO}_{x}$ are therefore targeted by the emission legislation presented by the international maritime organization (IMO) through the protocol of MARPOL 73/78 Annex VI[10].

$\mathrm{SO}_{\mathrm{x}}$ emissions are produced due to the sulfur content of the fuel oil used at a ship, and MARPOL Annex VI regulation 14 therefore limits the fuel oil sulfur content to $3.5 \mathrm{wt} \%$ until 2020[11], after which the global value is further reduced to $0.5 \mathrm{wt} \%$ sulfur in the fuel oil or an equivalent treatment of the exhaust gas. Furthermore, since 2015 when sailing within $\mathrm{SO}_{x}$ emission control area's (SECA's) the sulfur emissions from the ship must be equivalent to using a fuel oil contain no more than $0.1 \mathrm{wt} \%$ sulfur. The currently known SECA's are the Baltic Sea, the North Sea, the North American sea area and the US Caribbean sea area[12].

$\mathrm{NO}_{\mathrm{x}}$ emissions are produced in high-temperature combustion zones within the combustion chamber, mainly through the Zeldovich mechanism, independent of the fuel oil used[13,14]. $\mathrm{NO}$ is the main contributor $(>90 \%)$ to the $\mathrm{NO}_{\mathrm{x}}$ emissions from diesel engines [15-19].

$\mathrm{NO}_{\mathrm{x}}$ emissions are targeted through the introduction of MARPOL Annex VI, regulation 13, Tier I (2000) and Tier II (2011), both of which were reachable by the use of primary methods which reduces the combustion temperature, and therefore, also the production of $\mathrm{NO}_{\mathrm{x}}$. With the introduction of MARPOL Annex VI Tier III (2016), 80\% NO reduction is required compared to the Tier I regulation. Tier III applies to all ships constructed after 2016 and when sailing within $\mathrm{NO}_{\mathrm{x}}$ emission control areas (NECA's), which currently is the North American sea area and the US Caribbean sea area[12].

The two leading global engine manufacturers, MAN Energy Solutions and Wärtsilä, have stated that multiple solutions exist to comply with the new $\mathrm{NO}_{x}$ regulation. At the moment the most favorable solutions are the use of either exhaust gas recirculation $(E G R)[3,20]$, 
selective catalytic reduction ( $\mathrm{SCR}$ ) of $\mathrm{NO}_{\mathrm{x}}$, or dual-fuel engines fueled by either conventional liquid marine fuels or liquid natural gas (LNG)[21]. In this article the focus will be on SCR of $\mathrm{NO}_{x}$.

SCR of $\mathrm{NO}_{x}$ was first introduced in the 1970's and 1980's for the removal of $\mathrm{NO}_{\mathrm{x}}$ from stationary applications such as power plants, waste incinerators and within the chemical industry $[15,22,23] . \mathrm{NO}_{x}$ is typically reduced over a catalyst containing 1-5 wt $\% \mathrm{~V}_{2} \mathrm{O}_{5} / \sim 10$ wt $\% \mathrm{WO}_{3} / \mathrm{TiO}_{2}$ (V-SCR catalyst) using an $\mathrm{N}$-containing reductant such as ammonia $\left(\mathrm{NH}_{3}\right)$ on stationary units or urea on mobile units, which decomposes into $\mathrm{NH}_{3}$ upon heating $[15,16,24,25]$. The SCR of $\mathrm{NO}_{x}$ typically proceeds at temperatures between 200$500^{\circ} \mathrm{C}$, during which $\mathrm{NO}$ is reduced according to Reaction (1) into harmless nitrogen and water. Depending on the applied ammonia to $\mathrm{NO}_{x}$ ratio (ANR), $\mathrm{NO}_{x}$ reductions above $90 \%$ is reachable.

$$
4 \mathrm{NO}+4 \mathrm{NH}_{3}+\mathrm{O}_{2} \rightarrow 4 \mathrm{~N}_{2}+6 \mathrm{H}_{2} \mathrm{O}
$$

A high sulfur fuel oil (approx. 2.5 wt\% sulfur[26]) is typically used within the marine industry, which results in concentrations of up to $600 \mathrm{ppm} \mathrm{SO}_{2}$ in the flue gas. Up to $10 \%$ of the $\mathrm{SO}_{2}$ is further oxidized into $\mathrm{SO}_{3}$ within the combustion chamber[27], and a small part of the remaining $\mathrm{SO}_{2}(1-3 \%[28,29])$ is oxidized across the $\mathrm{V}$-SCR catalyst according to Reaction (2). The V-SCR catalyst is not deactivated by the presence of $\mathrm{SO}_{2}$, however, when both $\mathrm{SO}_{3}, \mathrm{H}_{2} \mathrm{O}$, and $\mathrm{NH}_{3}$ are present in the exhaust gas, ammonium bisulfate (ABS, Reaction (3)) and ammonium sulfate (AS, Reaction (4)) may form when the exhaust gas is cooled[30-32].

$$
\begin{gathered}
\mathrm{SO}_{2}+1 / 2 \mathrm{O}_{2} \rightarrow \mathrm{SO}_{3} \\
\mathrm{NH}_{3}+\mathrm{SO}_{3}+\mathrm{H}_{2} \mathrm{O} \rightarrow \mathrm{NH}_{4} \mathrm{HSO}_{4} \\
2 \mathrm{NH}_{3}+\mathrm{SO}_{3}+\mathrm{H}_{2} \mathrm{O} \rightarrow\left(\mathrm{NH}_{4}\right)_{2} \mathrm{SO}_{4}
\end{gathered}
$$

The sulfates condense, creating solid residues, at temperatures below $260-300^{\circ} \mathrm{C}$, depending on the partial pressures of $\mathrm{NH}_{3}$ and $\mathrm{SO}_{3}$. If the sulfates condense at the surface or within the pores of the catalyst[30], the catalyst is deactivated by the fouling, and hence temperatures higher than about $300^{\circ} \mathrm{C}$ are required in order to keep the catalyst active in high sulfur environments, such as a ship. For the highly effective 2-Stroke marine diesel engine, such high temperatures are only continuously present upstream of the 
turbocharger, where an increased pressure of up to 5 bar also can be present depending on the engine load[20,33-38].

The research within SCR at elevated pressure is scarce and only a few previous studies have been published. Kröcher et al.[35] measured the effect of increased pressure on $\mathrm{NO}_{x}$ conversion over two monolith V-SCR catalysts $\left(1.47\right.$ wt\% $\left.\mathrm{V}_{2} \mathrm{O}_{5}\right)$ with either 87 or 225 channels pr. square inch (CPSI). The experiments were performed with 1000 ppm NO, $A N R>1$, at pressures of 1 bar, 2 bar, and 4 bar. They kept the partial pressure of NO and $\mathrm{NH}_{3}$ constant, and decreased the amount of catalyst inversely proportional to the pressure, so the actual gas residence time was independent of the reaction pressure. They noted that at low temperature $\left(200^{\circ} \mathrm{C}\right)$, the pressure had no effect on the $\mathrm{NO}_{\mathrm{x}}$ conversion. However, at higher temperatures $\left(>250^{\circ} \mathrm{C}\right)$ increased pressure resulted in a lower $\mathrm{NO}_{x}$ conversion, from $70 \%$ at 1 bar to $50 \%$ at 4 bar at $250^{\circ} \mathrm{C}$ using the $225 \mathrm{CPSI}$ catalyst. The loss in $\mathrm{NO}_{\mathrm{x}}$ conversion was attributed to increased diffusion limitations, due to the inverse proportionality between pressure and the binary diffusion coefficient[39].

Rammelt et al.[36] also investigated the effects of increased pressure on two V-SCR (1.9 wt\% $\mathrm{V}_{2} \mathrm{O}_{5}$ ) monolith catalysts with either 300 or 25 CPSI. In line with Kröcher et al.[35] the observed drop in $\mathrm{NO}_{x}$ conversion with pressure was more pronounced for the low CPSI catalyst, due to longer diffusion pathways.

The present study investigates SCR at elevated pressure, using both lab-scale packed bed reactors and bench-scale monoliths to test the effects of pressure on SCR kinetics. Furthermore, the transient adsorption and desorption of $\mathrm{NH}_{3}$ at increased pressures up to 4.5 bar are investigated to reveal information of the changes in $\mathrm{NH}_{3}$ adsorption with pressure. Based on the experiments, both steady state SCR kinetics and dynamic adsorption and desorption processes are modeled. The side reaction of $\mathrm{SO}_{2}$ oxidation was published in a previous study by Christensen et al.[40].

\section{Experimental Methods}

\section{Lab-scale Setup}

\section{Apparatus}

The packed bed reactor shown schematically in Fig. 1 was used for kinetic SCR studies up to five bar. Four mass flow controllers from Brooks (SLA5850) controlled the gas composition. Water was added by the use of a HPLC pump (Gilson 307), and carried 
together with air, nitrogen, and ammonia into the homemade evaporator (H1), which consisted of 0.5 meter $1 / 8$ inch 316 steel tube which was coiled together with heat tracing (HSS from Lund \& Sørensen) and operated at a temperature of $350^{\circ} \mathrm{C}$. After the evaporator, all tubes were heat traced to $150^{\circ} \mathrm{C}$ to ensure that water vapor did not condense. NO was added to the hot gas downstream of the evaporator, to ensure that the oxidation of $\mathrm{NO}$ into $\mathrm{NO}_{2}$ was low, similar to diesel engine conditions ( $\mathrm{NO}>90 \%$ NO $[41])$.

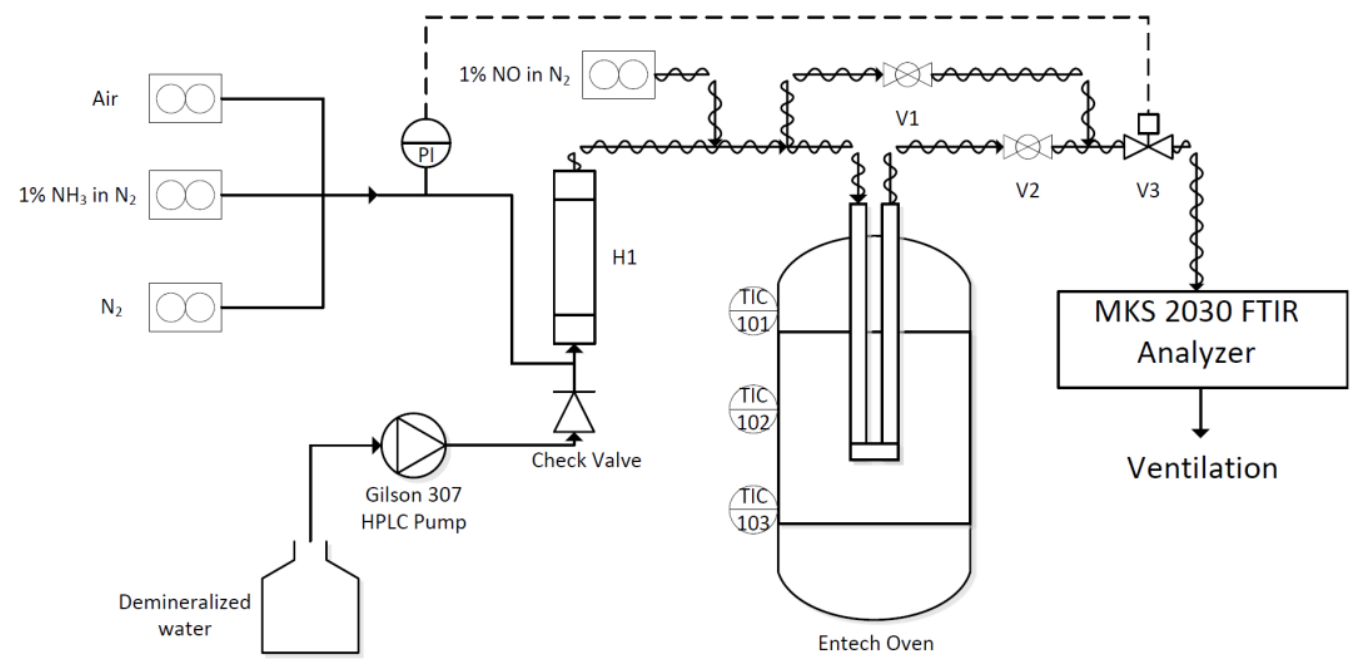

Fig. 1 The lab-scale test setup used for SCR experiments and $\mathrm{NH}_{3}$ TPD experiments at elevated pressure using a granulated V-SCR catalyst

The synthetic gas mixture was passed through a packed bed reactor, contained within a U-type quartz reactor. The position of the catalytic bed was maintained by a quartz wool plug on both sides, and a constriction of the glass tube, beneath the catalyst bed. A thermocouple was placed before the catalytic bed, to measure the temperature. After the reactor, the pressure was reduced by two automatic back pressure valves (Fisher Fieldvue DVC 2000), and gas concentrations were measured at atmospheric pressure using an MKS Multigas 2030 FTIR analyzer.

\section{Catalyst}

An SCR catalyst containing approximately $1 \mathrm{wt} \% \mathrm{~V}_{2} \mathrm{O}_{5} / 10 \mathrm{wt} \% \mathrm{WO}_{3} / \mathrm{TiO}_{2}$ (V-SCR) was supplied by Umicore Denmark ApS. The catalyst was produced as a monolith, from which the catalyst powder was obtained by crushing and removal of visible fibers. The powder was pressed into self-supporting pellets, which were crushed and sieved into catalyst particles with a size fraction of 150-300 micron, and loaded in the reactor setup. The 
fraction of 150-300 micron was chosen to diminish diffusion limitations, as shown in the online supplementary material.

\section{Steady State SCR - Experimental Methodology}

Approximately $20 \mathrm{mg}$ of catalyst was loaded in a U-type quartz reactor (as shown in Fig. 2a) with an inner diameter of $3 \mathrm{~mm}$, resulting in a bed height of $4 \mathrm{~mm}$. Catalysts were degreened for 20 hours at $410^{\circ} \mathrm{C}$ and 4.8 bar using a volumetric flow rate of 1200 $\mathrm{NmL} /$ min, containing $10 \% \mathrm{O}_{2}, 8 \% \mathrm{H}_{2} \mathrm{O}, 600$ ppm NO $\mathrm{N}_{x} 720$ ppm NH $\mathrm{N}_{3}$ in $\mathrm{N}_{2}$.

After degreening, steady state SCR experiments were carried out with typical gas concentrations of $10 \% \mathrm{O}_{2}, 8 \% \mathrm{H}_{2} \mathrm{O}, 600 \mathrm{ppm} \mathrm{NO}$, and an ammonia to $\mathrm{NO}_{x}$ ratio (ANR) of 0.8-1.2 in $\mathrm{N}_{2}$. The pressure was varied in steps of 1.2 bar up to 4.8 bar. The residence time within the catalyst bed was kept independent of pressure by increasing the total volumetric flow rate proportional with the pressure as shown in Equation (5):

$$
Q_{\text {total@P }}=Q_{0} \cdot \frac{P_{\text {reactor }}}{1 \text { atm }}
$$

Here $Q_{0}$ is the design total volumetric flow rate (normal $\left.\left(0^{\circ} \mathrm{C}, 1 \mathrm{~atm}\right)\right)$ used at $1 \mathrm{~atm}, P_{\text {reactor }}$ is the reactor pressure, and $Q_{\text {total@p }}$ is the total volumetric flow rate calculated for the specific pressure. At 1.2 bar a total volumetric flow rate of $300 \mathrm{NmL} / \mathrm{min}$ was used and at 4.8 bar a total volumetric flow rate of $1200 \mathrm{NmL} / \mathrm{min}$ was used. The gas outlet concentrations were continuously measured by the FTIR analyzer using the mean results of 16 spectra pr. sample resulting in gas concentration outputs every $16^{\text {th }}$ second.

\section{$\mathrm{NH}_{3} \mathrm{TPD}-$ Experimental Methodology}

Approximately $115 \mathrm{mg}$ of catalyst loaded in a U-type quartz reactor, with an inner diameter of $4 \mathrm{~mm}$. The catalyst was degreened for 20 hours at $410^{\circ} \mathrm{C}$ and 4.5 bar using a total volumetric flow rate of $600 \mathrm{NmL} /$ min containing $9 \% \mathrm{O}_{2}, 8 \% \mathrm{H}_{2} \mathrm{O}$ in $\mathrm{N}_{2}$. The increased reactor diameter was used to decrease the pressure drop over the increased amount of catalyst, compared to the steady state SCR experiments.

The $\mathrm{NH}_{3}$ temperature programmed desorption ( $\mathrm{NH}_{3} \mathrm{TPD}$ ) experiments consisted of 1 hour of $\mathrm{NH}_{3}$ adsorption at a specific temperature $\left(150^{\circ} \mathrm{C}, 200^{\circ} \mathrm{C}, 250^{\circ} \mathrm{C}\right.$ and $\left.300^{\circ} \mathrm{C}\right)$ and pressure using a flow of $300 \mathrm{NmL} /$ min containing $9 \% \mathrm{O}_{2}, 8 \% \mathrm{H}_{2} \mathrm{O}, 600 \mathrm{ppm} \mathrm{NH} \mathrm{N}_{3}$ in $\mathrm{N}_{2}$. During $\mathrm{NH}_{3}$ TPD experiments the total volumetric flow rate was kept constant at $300 \mathrm{NmL} / \mathrm{min}$. After 1 hour, the outlet concentration of $\mathrm{NH}_{3}$ was the same as the inlet concentration, i.e. the 
catalyst surface was saturated, and the flow of $\mathrm{NH}_{3}$ and $\mathrm{H}_{2} \mathrm{O}$ was stopped. Feeding of $\mathrm{H}_{2} \mathrm{O}$ was stopped to remove small pulsations from the pumping and evaporation of $\mathrm{H}_{2} \mathrm{O}$, so the desorption curve was smooth. During desorption, a total volumetric flow rate of 300 $\mathrm{NmL} / \mathrm{min}$ was used at 1 bar, while in all other experiments, a total volumetric flow rate of $276 \mathrm{NmL} / \mathrm{min}$ was used due to slightly different setpoints of the MFC setting for the nitrogen flow. After flushing for 1 hour a temperature ramp $(10 \mathrm{~K} / \mathrm{min})$ was performed from the saturation temperature and until $420^{\circ} \mathrm{C}$. The temperature was maintained at $420^{\circ} \mathrm{C}$ for $20 \mathrm{~min}$ before the reactor was cooled to the next adsorption temperature. The gas outlet concentrations were continuously measured by the FTIR analyzer using the mean of two spectra pr. sample resulting in gas concentration outputs every 2 seconds.

During $\mathrm{NH}_{3}$ adsorption the outlet concentration was observed to correspond to the inlet concentration indicating the no $\mathrm{NH}_{3}$ oxidation was present at any adsorption temperatures $\left(150-300^{\circ} \mathrm{C}\right)$. Ammonia oxidation could occur under the desorption, however, for low vanadium based catalyst $\mathrm{NH}_{3}$ oxidation is first expected at temperatures well above $350^{\circ} \mathrm{C}$, during which most of the $\mathrm{NH}_{3}$ has been desorbed. Therefore, $\mathrm{NH}_{3}$ oxidation has been disregarded.

Blank experiments (i.e., no catalyst loaded) were performed to examine the response of the setup when $\mathrm{NH}_{3}$ addition was stopped. The first blank experiment was performed at 1.2 bar, with $\mathrm{NH}_{3}$ adsorption steps at $150^{\circ} \mathrm{C}, 200^{\circ} \mathrm{C}, 250^{\circ} \mathrm{C}$ and $300^{\circ} \mathrm{C}$ all followed by the described heating ramp. However, since no change was observed between the different temperatures, the ramp was skipped, and the blank experiments were performed without the ramp to save time and only at a temperature of $150^{\circ} \mathrm{C}$. Because the ramp was skipped, the blank experiments were shorter than the actual experiment.

\section{Bench-Scale Setup}

\section{Apparatus}

Experiments using monolith catalyst elements at elevated pressure were performed with the setup previously described in detail, for the measurements of pressurized $\mathrm{SO}_{2}$ oxidation over a V-SCR catalyst by Christensen et al.[40]. The setup is a bench-scale setup for testing monolith catalysts using Brooks smart flow controllers for gasses (Air, $\mathrm{N}_{2}, \mathrm{NO}$, and $\mathrm{NH}_{3}$ ) and Brooks liquid mass flow controller (model 5882) for water addition. Air, nitrogen and water were passed through a preheater, in which water was evaporated. The gas mixture was further heated in a second heater, after which $\mathrm{NH}_{3}$ and $\mathrm{NO}$ were 
added upstream of a static mixer from Sulzer, from which the hot mixed gas was passed through the monolith catalyst. The catalyst was placed within a square electrically heated furnace, and gas analysis was performed using a Gasmet FTIR analyzer (GASMET DX 4000 ) by withdrawal of gas before and after the catalyst, allowing the conversion of $\mathrm{NO}_{x}$ to be determined.

\section{Catalyst}

A V-SCR monolith catalyst ( $1 \mathrm{wt} \% \mathrm{~V}_{2} \mathrm{O}_{5} / 10 \mathrm{wt} \% \mathrm{WO}_{3} / \mathrm{TiO}_{2}$ ) was cut into a square crosssectional area $(43.5 \mathrm{~mm})$, and a length of $99.1 \mathrm{~mm}$ and the sides were sealed with quartz wool. Furthermore, to reduce external mass transfer limitations and the $\mathrm{NO}_{\mathrm{x}}$ conversion, all but 9 channels of the monolith were sealed resulting in an open area of $223 \mathrm{~mm}^{2}$ i.e. area without the channel walls, as shown in Fig. $\mathbf{2 b}$.

a)

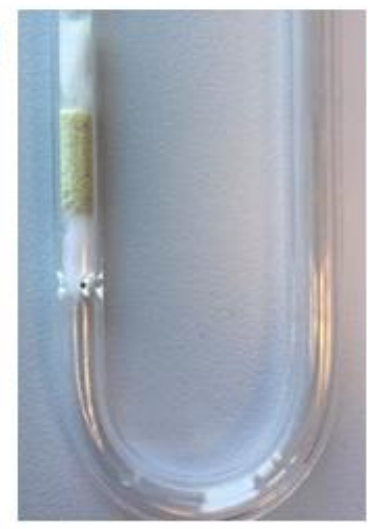

b)

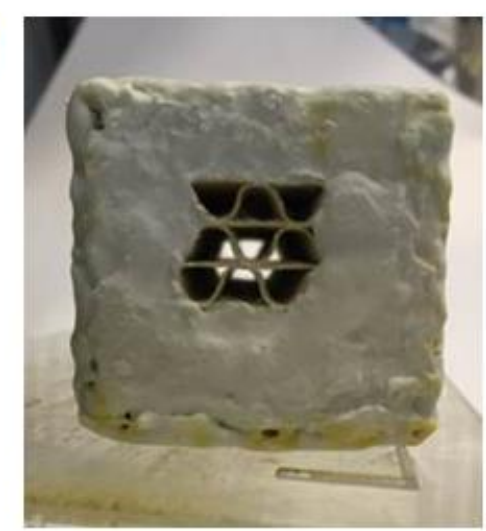

Fig. 2 Granulated catalyst particles in a packed bed reactor (PBR) (a) and the monolith catalyst with 9 open channels (b)

\section{Steady State SCR - Experimental Methodology}

The monolith was loaded into the reactor setup, and the catalyst was degreened at $410^{\circ} \mathrm{C}$ in a flow of air and $5 \% \mathrm{H}_{2} \mathrm{O}$ for 15 hours. The SCR reaction was performed at 1 and 3 bar while keeping the residence time independent of the pressure as shown in Equation (5). At 1 bar a flow of $4.9 \mathrm{Nm}^{3} / \mathrm{h}$ was used containing $8 \% \mathrm{O}_{2}, 5 \% \mathrm{H}_{2} \mathrm{O}, 720 \mathrm{ppm} \mathrm{NO}$, and ANR $=0.75$ or 1.16 in $\mathrm{N}_{2}$. 


\section{Results}

\section{High Pressure Steady State SCR Experiments}

The SCR experiments were carried out at steady state conditions and the measured $\mathrm{NO}_{\mathrm{x}}$ conversion as a function of temperature is shown for ANR $=1.2$ and ANR $=0.8$ in Fig. 3.

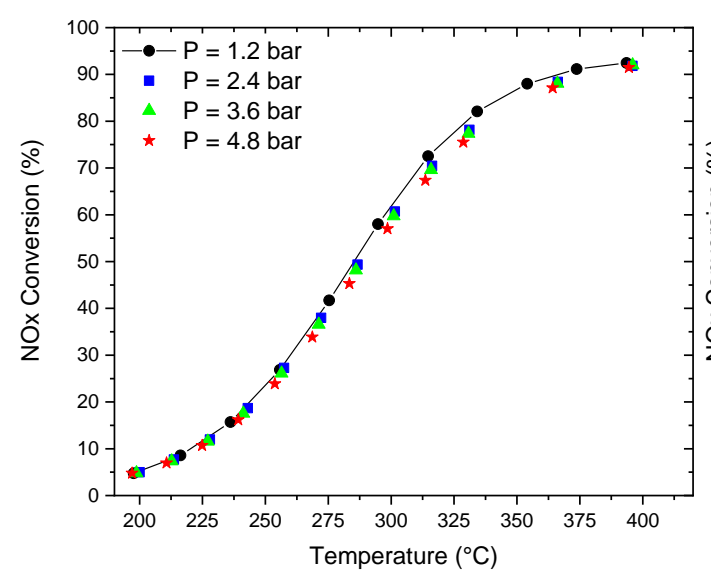

Fig. $3 a \mathrm{ANR}=1.2$

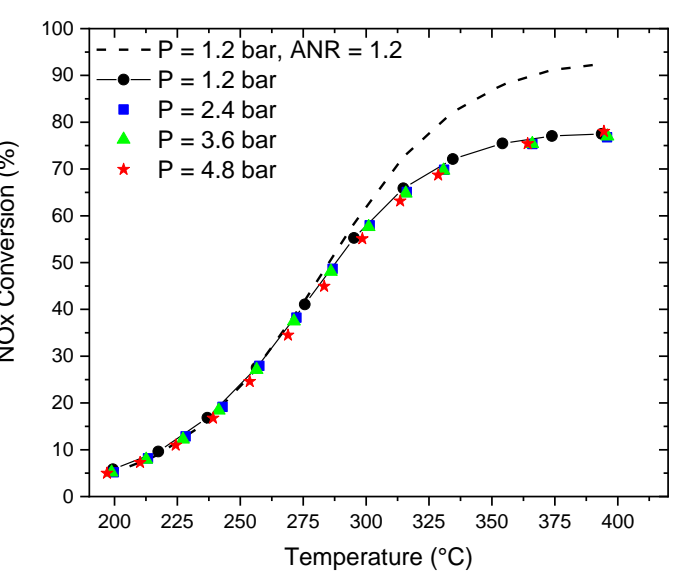

Fig. $3 b$ ANR $=0.8$

Fig. 3 Packed bed steady state SCR experiments using $20.8 \mathrm{mg}\left(\sim 1 \mathrm{wt} \% \mathrm{~V}_{2} \mathrm{O}_{5}\right)$ V-SCR catalyst and a flow of $300 \mathrm{NmL} / \mathrm{min}$ at 1.2 bar containing $10 \% \mathrm{O}_{2}, 8 \% \mathrm{H}_{2} \mathrm{O}, 600 \mathrm{ppm} \mathrm{NO}{ }_{x}, A N R=1.2$ (a) or $\mathrm{ANR}=$ 0.8 (b) in $N_{2}$. The residence time was kept constant by increasing the total volumetric flow rate according to Eq. (5)

Fig. 3 shows that the $\mathrm{NO}_{x}$ conversion is independent of the pressure when the residence time is kept constant. The $\mathrm{NH}_{3}$ and $\mathrm{NO}_{\mathrm{x}}$ consumption was found to follow the stoichiometry according to reaction (1) (1:1), within $5 \%$ of the total $\mathrm{NO}_{\mathrm{x}}$ concentration, or at low concentration $(<100 \mathrm{ppm})$ where differences in gas measurements gives a large error within $15 \mathrm{ppm}$. Formation of other byproducts such as $\mathrm{N}_{2} \mathrm{O}$ from $\mathrm{NH}_{3}$ oxidation was not observed at any conditions. At atmospheric pressure water is known to limit the formation of $\mathrm{N}_{2} \mathrm{O}$ across $\mathrm{V}$-SCR due to competitive adsorption[7,24], which also seems to apply for increased pressure. Fig. 3 shows that the kinetics of the SCR reaction are not affected by pressures up to 4.8 bar. The small variations observed are within the experimental uncertainty. Furthermore, Fig. 3b shows that when $\mathrm{NH}_{3}$ becomes the limiting reactant at high temperatures the conversion of $\mathrm{NO}_{x}$ levels off at a $\mathrm{NO}_{x}$ conversion 
close to the ANR value, as also typically reported for atmospheric pressures. The fact that the SCR reaction is not affected by the increased pressure also means that a regular kinetic expression $[15,24,42,43]$ taking into account the $\mathrm{NH}_{3}$ surface coverage can be used, either in more complicated forms of Temkin isotherms as discussed later or using regular Langmuir isotherms as in the simplified Eley-Rideal mechanism[42] as given in Equation (6). Fig. 3a also indicates that the reaction can be treated as a first order reaction at ANR $>1$, because the conversion is not changed when the pressure is increased, i.e. no changes at increased partial pressures.

$$
R_{N O}=k_{N O} \cdot C_{N O} \frac{K_{N H 3} \cdot C_{N H 3}}{1+K_{N H 3} \cdot C_{N H 3}}
$$

The addition of $\mathrm{NO}$ to the hot gas ensured that the maximum concentration of $\mathrm{NO}_{2}$ in the feed gas was 40 ppm NO$~_{2}$ (at 4.8 bar) out of a total $\mathrm{NO}_{x}$ concentration of 600 ppm, which was not observed to change the $\mathrm{NO}_{\mathrm{x}}$ reduction so the reaction can be modelled as only the standard SCR reaction, i.e., considering all $\mathrm{NO}_{x}$ as $\mathrm{NO}$.

To investigate the NO reaction order, inlet NO concentrations of 300,600 , and $900 \mathrm{ppm}$ $\mathrm{NO}_{\mathrm{x}}$ were used, with constant residence time and using an ANR of 0.8 or 1.2 as shown in

Fig. 4.

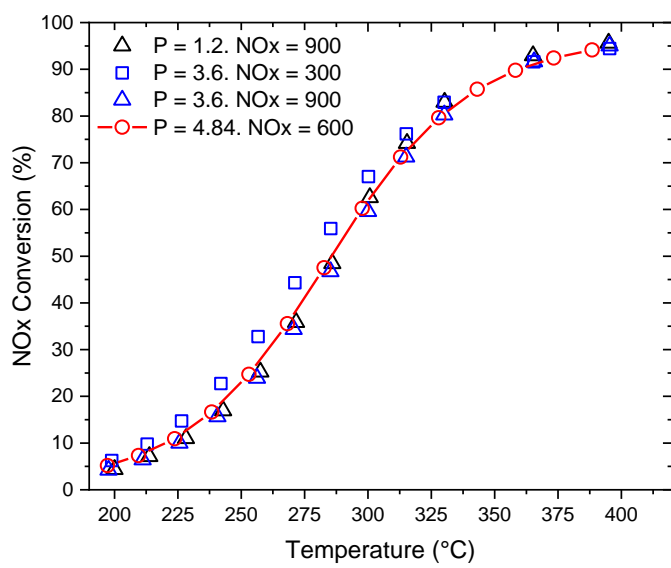

Fig. $4 a$ ANR $=1.2$

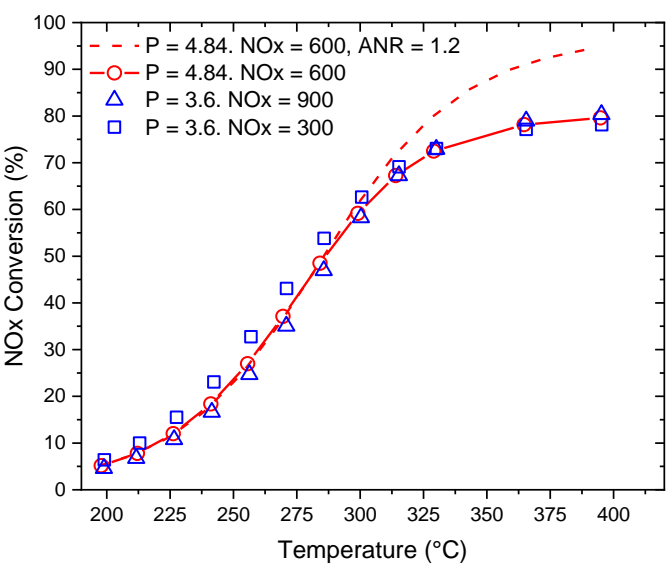

Fig. $4 \mathrm{~b}$ ANR $=0.8$

Fig. 4 Packed bed steady state SCR experiments using $20.5 \mathrm{mg}\left(\sim 1 \mathrm{wt} \% \mathrm{~V}_{2} \mathrm{O}_{5}\right)$ V-SCR catalyst and a flow rate of $300 \mathrm{NmL} / \mathrm{min}$ at 1.2 bar containing $10 \% \mathrm{O}_{2}, 5 \% \mathrm{H}_{2} \mathrm{O}, 300,600$, or 900 ppm NO , ANR = 1.2 (a) or $A N R=0.8$ (b) in $N_{2}$. The residence time was kept constant by increasing the total volumetric flow rate according to Eq. (5) 
Fig. 4 shows that changing the inlet $\mathrm{NO}_{\mathrm{x}}$ concentration from $600 \mathrm{ppm}$ to $900 \mathrm{ppm}$ did not affect the $\mathrm{NO}_{\mathrm{x}}$ conversion as expected for a reaction that is first order in NO. The $\mathrm{NO}_{2}$ concentration increased to $50 \mathrm{ppm}$ for the case of $900 \mathrm{ppm} \mathrm{NO}$ x at 3.6 bar, i.e., $94 \%$ of $\mathrm{NO}_{\mathrm{x}}$ is $\mathrm{NO}$, and the assumption of only standard SCR is still applicable. When the inlet $\mathrm{NO}_{\mathrm{x}}$ concentration was lowered to $300 \mathrm{ppm}$ (at $3.6 \mathrm{bar}$ ), the $\mathrm{NO}_{\mathrm{x}}$ conversion unexpectedly increased at the lower temperature range which is expected to be due to an unintended increased residence time within the catalyst. A concentration of $300 \mathrm{ppm}$ of $\mathrm{NO}_{\mathrm{x}}$ is well within normal atmospheric SCR operation[24,44]. The expected effects of increased pressure, includes increased $\mathrm{NH}_{3}$ adsorption, decreased diffusivity, and the possibility of increased formation of $\mathrm{NO}_{2}$. The increased $\mathrm{NH}_{3}$ adsorption at increased pressure should not affect an experiment with ANR $=1.2$, because the rate of NO reaction is independent of $\mathrm{NH}_{3}$ coverage, as also will be shown later. Furthermore, the behavior should have been visible independently of the $\mathrm{NO}_{\mathrm{x}}$ inlet concentration. A decrease in diffusivity would lower the $\mathrm{NO}_{x}$ conversion and is first observed in diffusion controlled operation, such as a monolith, and again should be present independently of the $\mathrm{NO}_{\mathrm{x}}$ inlet concentration. Lastly, increased formation of $\mathrm{NO}_{2}$ at increased pressure was observed, however, never exceeding $6 \%$ of the total $\mathrm{NO}_{\mathrm{x}}$ and the effect is more pronounced at increased $\mathrm{NO}_{\mathrm{x}}$ concentrations due to a second order reaction dependency in NO for the NO oxidation[45]. Therefore, the change in conversion observed with an inlet concentration of $300 \mathrm{ppm} \mathrm{NO}$ at an ANR of 1.2 or 0.8 is likely due to an unintended lower total volumetric flow rate, resulting in increased residence time.

\section{$\mathrm{NH}_{3}$ TPD at elevated pressure}

$\mathrm{NH}_{3}$ TPD experiments were performed at $1.2,2.4,3.6$ and 4.5 bar using a total volumetric flow rate during adsorption of $300 \mathrm{NmL} /$ min containing $9 \% \mathrm{O}_{2}, 8 \% \mathrm{H}_{2} \mathrm{O}$, and $600 \mathrm{ppm} \mathrm{\textrm {NH } _ { 3 }}$ in $\mathrm{N}_{2}$. A typical set of data for TPD at 1.2 bar is shown in Fig. 5. Similar plots for 2.4, 3.6 and 4.5 bar and a zoom of the $\mathrm{NH}_{3}$ peaks can be found in the online supplementary material. 


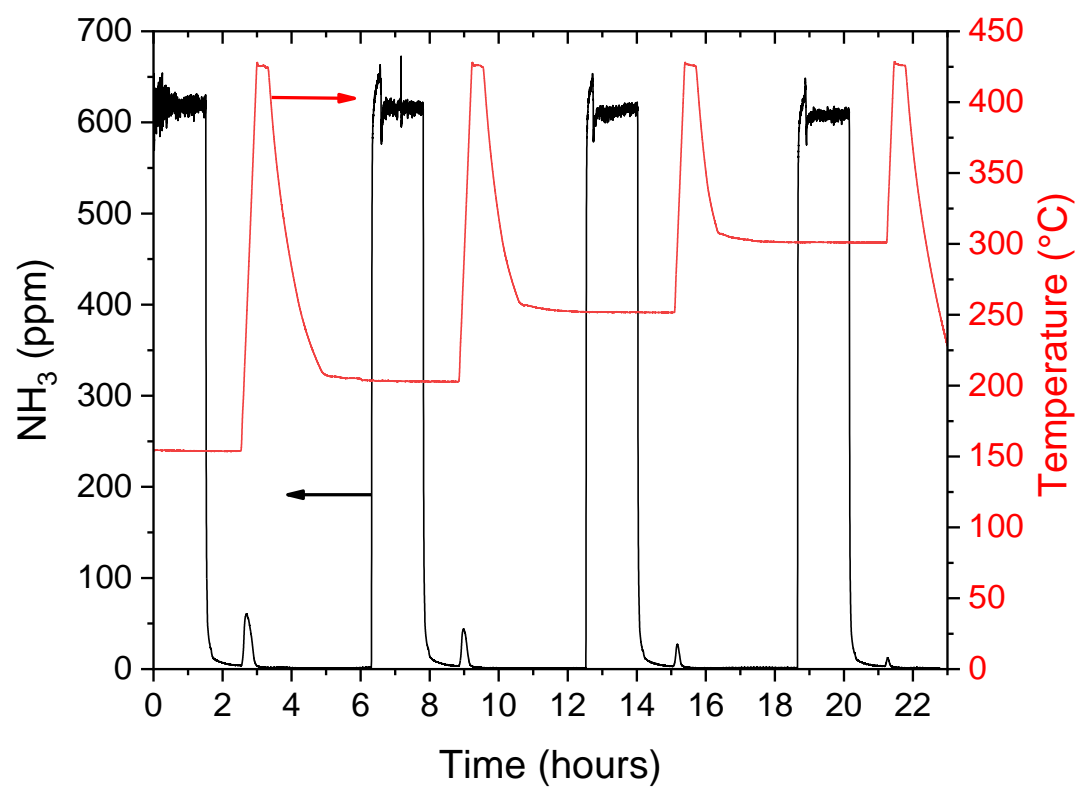

Fig. $5 \mathrm{NH}_{3}$ TPD at a pressure of 1.2 bar. $\mathrm{NH}_{3}$ adsorption is performed at four different temperatures $\left(150,200,250\right.$, and $\left.300^{\circ} \mathrm{C}\right)$, using a total volumetric flow rate during adsorption of $300 \mathrm{NmL} / \mathrm{min}$ containing $9 \% \mathrm{O}_{2}, 8 \% \mathrm{H}_{2} \mathrm{O}, \sim 600 \mathrm{ppm} \mathrm{NH}_{3}$ in $\mathrm{N}_{2}$

Fig. 5 shows that loosely bound $\mathrm{NH}_{3}$ desorbs during the 1 hour flush, while the rest of the

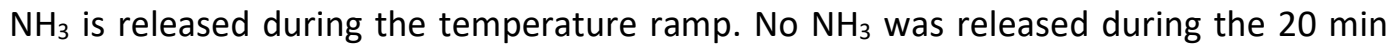
isotherm at $420^{\circ} \mathrm{C}$. Integration of the data for the desorption of $\mathrm{NH}_{3}$ was performed at each pressure and temperature, to calculate the amount of $\mathrm{NH}_{3}$ adsorbed on the surface of the catalyst. Integration of the full desorption curve was performed, but also the heating ramp peak only. The blank experiments, performed without a catalyst, resulted in full desorption backgrounds of $97,150,166$, and $166 \mu \mathrm{mol} / \mathrm{g}_{\text {cat }} \mathrm{NH}_{3}$ at $150^{\circ} \mathrm{C}$, and a pressure of 1.2, 2.4, 3.6, and 4.5 bar respectively. The background integration was divided by the amount of catalyst used in the actual experiments, to ease comparison. The backgrounds were withdrawn from the integration, and the $\mathrm{NH}_{3}$ adsorbed on the surface of the catalyst was calculated as shown in Fig. 6 .
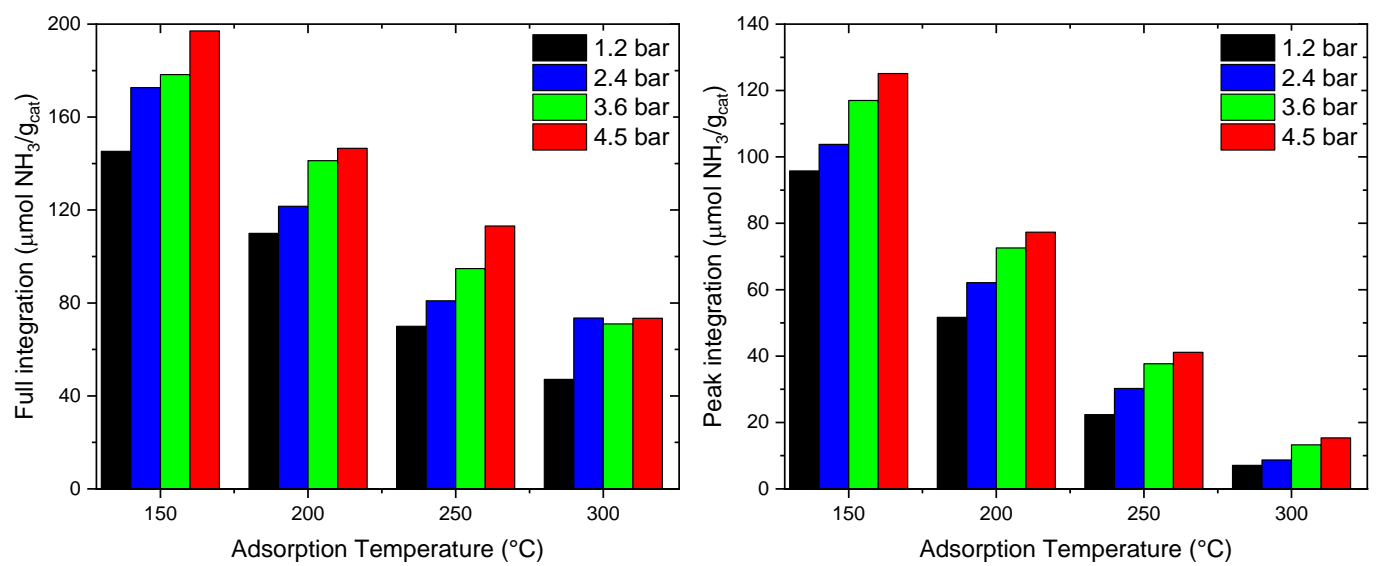
Fig. 6a Integration of the full desorption trace of $\mathrm{NH}_{3}$
Fig. $\mathbf{6 b}$ Integration of the desorption peak

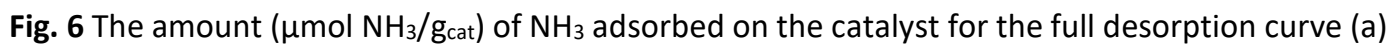
and for the desorption peak during the ramp (b). It should be noted that the measured blank values have been subtracted for both cases

Fig. 6 shows that in general the ammonia adsorption increases as the pressure increases, and that the ammonia adsorption decreases as the adsorption temperature increases. Fig. 6 a shows that at the high adsorption temperature of $300^{\circ} \mathrm{C}$, the adsorption capacity of the catalyst is similar at pressures above 2.4 bar. At this high temperature, the amount of $\mathrm{NH}_{3}$ stored on the catalyst is low, and hence, the small increase, at increased pressure, is likely hidden within the uncertainty ( $\pm 5 \%$ of the mean) of the blank experiments. Fig. $6 \mathrm{~b}$ shows more clearly the increased adsorption at increased pressure, also at $300^{\circ} \mathrm{C}$. It should be noted, that even though the $\mathrm{NH}_{3}$ adsorption increases with the increasing pressure, the steady state $\mathrm{NO}_{x}$ reduction was found to be independent of the pressure, and hence does not affect the SCR reaction, as will be further discussed during the kinetic modeling.

Fig. 6a shows that by increasing the pressure 3.8 times (from 1.2 to 4.5 bar), the amount of $\mathrm{NH}_{3}$ stored on the catalyst increases by $36 \%$ at a temperature of $150^{\circ} \mathrm{C}$. Bank et al.[34] reported for a washcoated monolith, that the integral ammonia storage for a $100 \mathrm{cpsi}$ vanadium based SCR catalyst increased by approximately $70 \%$ by changing the pressure from 1 bar to 2 bar at $215^{\circ} \mathrm{C}$. The reason for the difference between the results reported by Bank et al. and the results obtained here is not clear, but may be related to the catalyst composition which was not disclosed in their study. Furthermore, Bank et al.[34] did not report if blank experiments were performed and subtracted, which is an important issue due to the increased mass of gas contained within the setup at increased pressure. For instance, if the blank is not subtracted, the adsorption at $150^{\circ} \mathrm{C}$ increases by $46 \%$ instead of $35 \%$ when the pressure is increased by a factor 4 . The blank experiments depends on the dynamics of the experimental facility, and for larger facilities, for instance using monoliths such as that used by Bank et al.[34], the effect of the blank experiment is expected to increase. 


\section{Modeling of the Transient Adsorption/Desorption Experiments}

A transient model was set up in order to obtain the kinetics describing the adsorptiondesorption processes. The gas phase concentration of $\mathrm{NH}_{3}$ was modeled similarly to Lietti et al.[46] as an isothermal plug flow reactor, which was simplified in this study as a number of CSTR's in series. Diffusion limitations and axial dispersion were estimated to be negligible as shown in the online supplementary material. The gas phase concentration and the surface coverage of $\mathrm{NH}_{3}$ are therefore given by Equation (7) and (8).

$$
\begin{gathered}
\frac{d C_{N}}{d t}=\frac{v_{0}}{\varepsilon \cdot V_{N}} \cdot\left(C_{N-1}-C_{N}\right)+\left(r_{d, N}-r_{a, N}\right) \cdot \frac{1-\varepsilon}{\varepsilon} \cdot \Omega^{\prime} \\
\frac{d \theta_{N}}{d t}=r_{a, N}-r_{d, N}
\end{gathered}
$$

Here $\mathrm{N}$ is the CSTR number, $\mathrm{C}_{\mathrm{N}}$ is the $\mathrm{NH}_{3}$ concentration out of the $\mathrm{N}^{\text {th }}$ CSTR, $\mathrm{C}_{\mathrm{N}-1}$ is the inlet concentration of $\mathrm{NH}_{3}, v_{0}$ is the volumetric flow rate, $V_{N}$ is the volume of the $\mathrm{N}^{\text {th }}$ CSTR, $\varepsilon$ is the interparticle porosity of the reactor volume, $\Omega^{\prime}$ is the $\mathrm{NH}_{3}$ adsorption capacity $\left(\mathrm{mol} / \mathrm{m}^{3}\right.$ particles), the density of the particles are $1236 \mathrm{~kg} / \mathrm{m}^{3}$ particles, $\theta_{N}$ is the surface coverage of $\mathrm{NH}_{3}$ and $r_{a, N}$ and $r_{d, N}$ are the rate of adsorption and the rate of desorption. The rate of adsorption and desorption is given by Equation (9) and Equation (10) respectively.

$$
\begin{gathered}
r_{a, N}=k_{a}^{0} \cdot \exp \left(\frac{-E_{a}}{R \cdot T}\right) \cdot C_{N} \cdot\left(1-\theta_{N}\right) \\
r_{d, N}=k_{d}^{0} \cdot \exp \left(\frac{-E_{d}^{0} \cdot\left(1-\alpha \cdot \theta_{N}\right)}{R \cdot T}\right) \cdot \theta_{N}
\end{gathered}
$$

Here $k_{a}^{0}$ and $\mathrm{E}_{\mathrm{a}}$ are the pre-exponential factor and the activation energy of the adsorption process, and $k_{d}^{0}$ and $E_{d}^{0}$ are the pre-exponential factor and the activation energy for the desorption process. $\alpha$ is a parameter in the Temkin isotherm. The Temkin isotherm was reported by Lietti et al.[46] to provide a better fit compared to a regular Langmuir isotherm $(\alpha=0)$. A non-zero value of alpha induces a linear decrease in activation energy for desorption as the surface of the catalyst is filled by the adsorbate $(\theta \rightarrow 1)$. Lietti et al.[46] found that the rate of adsorption was well represented by a non-activated $\left(E_{a}=0\right)$ process in line with the adsorption of an alkaline specie, such as $\mathrm{NH}_{3}$, on the acidic surface cites of the catalyst, which will also be used in this study. 


\section{Transient Model Fitting}

The unknown adsorption and desorption kinetic parameters, i.e. $k_{a}^{0}, k_{d}^{0}, E_{d}^{0}, \alpha$, and $\Omega^{\prime}$ were fitted by the use of Matlab's ${ }^{\circledR}$ function "fmincon" using 30 CSTR's in series. According to Levenspiel [47] the number of CSTR's in series that should be used to approximate the flow profile in a fixed bed is given by Equation (11)

$$
N_{\text {tanks }}=n_{\text {particles }}
$$

With a bed height of $12 \mathrm{~mm}$ and a particle diameter of $150-300 \mu \mathrm{m}$, this results in $40-80$ tanks in series. 30 CSTR's in series were initially chosen to ensure fast simulation, and the final fitting was verified against a run with 80 tanks in series which did not change the fitting results. The fitting procedure minimizes the function given by Equation (12)

$$
F(x)=\sum\left(\frac{\left|y_{\text {meas }}-y_{\text {model }}\right|}{y_{\text {meas }}}\right)
$$

In which $y_{\text {meas }}$ and $y_{\text {model }}$ are vectors containing the measured and modeled gas phase $\mathrm{NH}_{3}$ concentration as a function of time. The blank experiments were difficult to subtract as a vector from the actual experiment, because the time signals do not fully overlay each other, and so it was decided to only fit the $\mathrm{NH}_{3}$ peak during the ramp of temperature, during which the background was negligible $(<3 \mathrm{ppm} \mathrm{NH})$.

The $\mathrm{NH}_{3}$ capacity of the catalyst $\left(\Omega^{\prime}\right)$ was calculated based on the data shown in Fig. 6 a, from which it was found that the $\mathrm{NH}_{3}$ capacity was highest at the lowest temperature $\left(150 \mathrm{C}^{\circ}\right)$ and the highest pressure (4.5 bar) tested. Therefore, the total $\mathrm{NH}_{3}$ adsorption capacity was calculated based on the measured total $\mathrm{NH}_{3}$ adsorption at $150^{\circ} \mathrm{C}$ and $4.5 \mathrm{bar}$ to $\Omega^{\prime}=228 \mathrm{~mol} \mathrm{NH} / \mathrm{m}^{3}$ particle. It is thus assumed that the surface of the catalyst is completely filled with $\mathrm{NH}_{3}(\theta=1)$ at a pressure of 4.5 bar and at a temperature of $150^{\circ} \mathrm{C}$. In case the model predicts a non-saturated surface, a new $\mathrm{NH}_{3}$ capacity should be calculated and a new fitting performed hence the calculation would be iterative. As shown later, the surface coverage is found to be close to $1(0.98)$. The $\mathrm{NH}_{3}$ capacity reported by Lietti et al.[46] was $270 \mathrm{~mol} \mathrm{NH} 3 / \mathrm{m}^{3}$ reactor for a similar ternary $1.47 \mathrm{wt} \% \mathrm{~V}_{2} \mathrm{O}_{5}-9 \mathrm{wt} \%$ $\mathrm{WO}_{3}-\mathrm{TiO}_{2}$ catalyst. As a comparison, the $\mathrm{NH}_{3}$ capacity found in this study in the same units give $372 \mathrm{~mol} \mathrm{NH} / \mathrm{m}^{3}$ reactor based upon the bed porosity, as shown in Equation (14). The bed porosity was calculated under the assumption of spherical particles based on the empirical formula presented by Pushnov[48] and shown in Equation (13). Pushnov reported an average deviation of the formula of $\pm 5.26 \%$. 


$$
\begin{gathered}
\varepsilon=\frac{1}{\left(D_{\text {reactor }} / d_{\text {particle }}\right)^{2}}+0.375=0.38 \\
\Omega=\Omega^{\prime} \cdot \frac{1-\varepsilon}{\varepsilon}=372 \frac{\text { mol }}{m^{3} \text { reactor }}
\end{gathered}
$$

The calculated $\mathrm{NH}_{3}$ capacity in the case of the pressurized experiments reported here is, therefore, higher than the one reported by Lietti et al.[46]. This is possibly due to the increased pressure used in this work and the fact that the catalysts are different. Lietti et al.[46] also reported the $\mathrm{NH}_{3}$ capacity for a binary catalyst $\left(\mathrm{V}_{2} \mathrm{O}_{5}-\mathrm{TiO}_{2}\right), 209 \mathrm{~mol} / \mathrm{m}^{3}$ reactor, and explained the difference due to changes in surface area, i.e., $46 \mathrm{~m}^{2} / \mathrm{g}_{\text {cat }}$ for the binary catalyst vs. $80 \mathrm{~m}^{2} / \mathrm{g}_{\text {cat }}$ for the ternary catalyst. For the catalyst used in this study a similar catalyst surface area as that for the ternary catalyst was found by $\mathrm{N}_{2}$ adsorption calculations (BET method). The difference in $\mathrm{NH}_{3}$ capacity can therefore not be explained by different surface areas.

With the $\mathrm{NH}_{3}$ capacity fixed at $228 \mathrm{~mol} \mathrm{NH}_{3} / \mathrm{m}^{3}$ particle ( $372 \mathrm{~mol} \mathrm{NH} / \mathrm{m}^{3}$ reactor), the four last fitting parameters $\left(k_{a}^{0}, k_{d}^{0}, E_{d}^{0}\right.$, and $\left.\alpha\right)$ were fitted using 30 CSTR's in series, only fitting the $\mathrm{NH}_{3}$ peaks, however, using the combined data with all pressures and temperatures. Based on different initial guesses, it was found that the model was able to find different parameter values that fitted the data equally well. Therefore, the quality of an individual fit was evaluated based on how well the $\mathrm{NH}_{3}$ adsorption and desorption kinetics were able to predict the steady state NO conversion presented earlier. It was found that the adsorption constant $\left(k_{a}^{0}\right)$ should be large in order to predict a correct surface coverage of the catalyst, which also was able to predict the observed $\mathrm{NO}_{\mathrm{x}}$ reduction during steady state SCR. The only solution that was found to both fit the $\mathrm{NH}_{3}$ TPD experiments and the steady state SCR experiments is shown in Table 1 in which the values reported in the article by Lietti et al.[46] are also shown for comparison.

Table 1 The fitted adsorption-desorption kinetic parameters including the parameters reported by Lietti et al.[46] for a ternary $1.47 \mathrm{wt} \% \mathrm{~V}_{2} \mathrm{O}_{5} / \mathrm{WO}_{3} / \mathrm{TiO}_{2}$ catalyst. $\Omega$ is in this study calculated based upon the amount of $\mathrm{NH}_{3}$ adsorbed at $150^{\circ} \mathrm{C}$ and 4.5 bar. $E_{a}$ is assumed to be zero in both studies

\begin{tabular}{ccccccc}
\hline Parameters & $k_{a}^{0}$ & $\mathrm{E}_{\mathrm{a}}$ & $k_{d}^{0}$ & $E_{d}^{0}$ & $\alpha$ & $\Omega$ \\
Units & $\mathrm{m}^{3} /(\mathrm{mol} \cdot \mathrm{s})$ & $\mathrm{kJ} / \mathrm{mol}$ & $1 / \mathrm{s}$ & $\mathrm{kJ} / \mathrm{mol}$ & - & $\mathrm{mol} / \mathrm{m}^{3}$ reactor \\
& & & & & & \\
\hline This study & 6.8 & 0 & $11 \cdot 10^{5}$ & 92.8 & 0.299 & 372
\end{tabular}


Most of the fitted values in this study are close to those reported by Lietti et al.[46], with the main difference being the rate of adsorption, which is more than ten times larger than that reported by Lietti et al. The increased rate of adsorption could be related to a more acidic catalyst, which is also in line with the higher $\mathrm{NH}_{3}$ capacity. It was noted that a similar kinetic constant was found across the different adsorption temperatures, again indicating that the pressure does not affect the kinetics. A plot of how well the model predicts the measured data is shown in Fig. 7 and Fig. 8 for 1.2 bar and 4.5 bar respectively. In the online supplementary material, a graph for each pressure (1.2 bar, 2.4 bar, 3.6 bar, and 4.5 bar) is shown together with a zoom of the $\mathrm{NH}_{3}$ peaks.

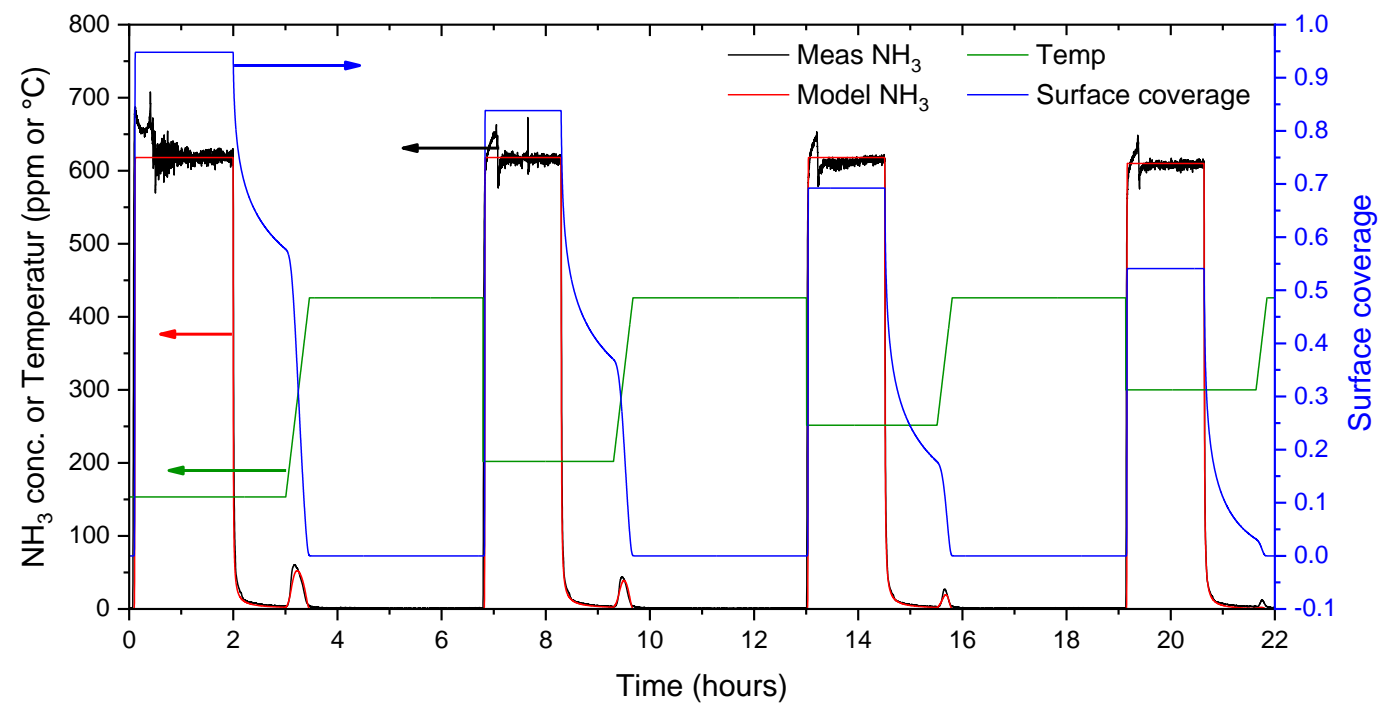

Fig. 7 Measured and predicted $\mathrm{NH}_{3}$ adsorption and desorption at 1.2 bar, using an $\mathrm{NH}_{3}$ concentration of $610 \mathrm{ppm}$, at four different temperatures $\left(150,200,250\right.$, and $\left.300^{\circ} \mathrm{C}\right)$. The model is based on the fitted parameters shown in Table 1. A zoom of the desorption peeks can be found in the supplementary material

From Fig. 7 (and the online material) it is observed that the model does not predict the desorption peak at $300^{\circ} \mathrm{C}$ and 1.2 bar that well since most of the $\mathrm{NH}_{3}$ is predicted to desorb during the 1-hour flush. At 4.5 bar (Fig. 8), however, the high temperature peak at $300^{\circ} \mathrm{C}$ is well fitted. Furthermore, from Fig. 8 it is observed that at a temperature of $150^{\circ} \mathrm{C}$ and 4.5 bar, the model predicts a surface coverage of 0.98 which is close to 1 , and so the fixed $\mathrm{NH}_{3}$ adsorption capacity $(\Omega)$ of $372 \mathrm{~mol} \mathrm{NH}_{3} / \mathrm{m}^{3}$ reactor is correct. 


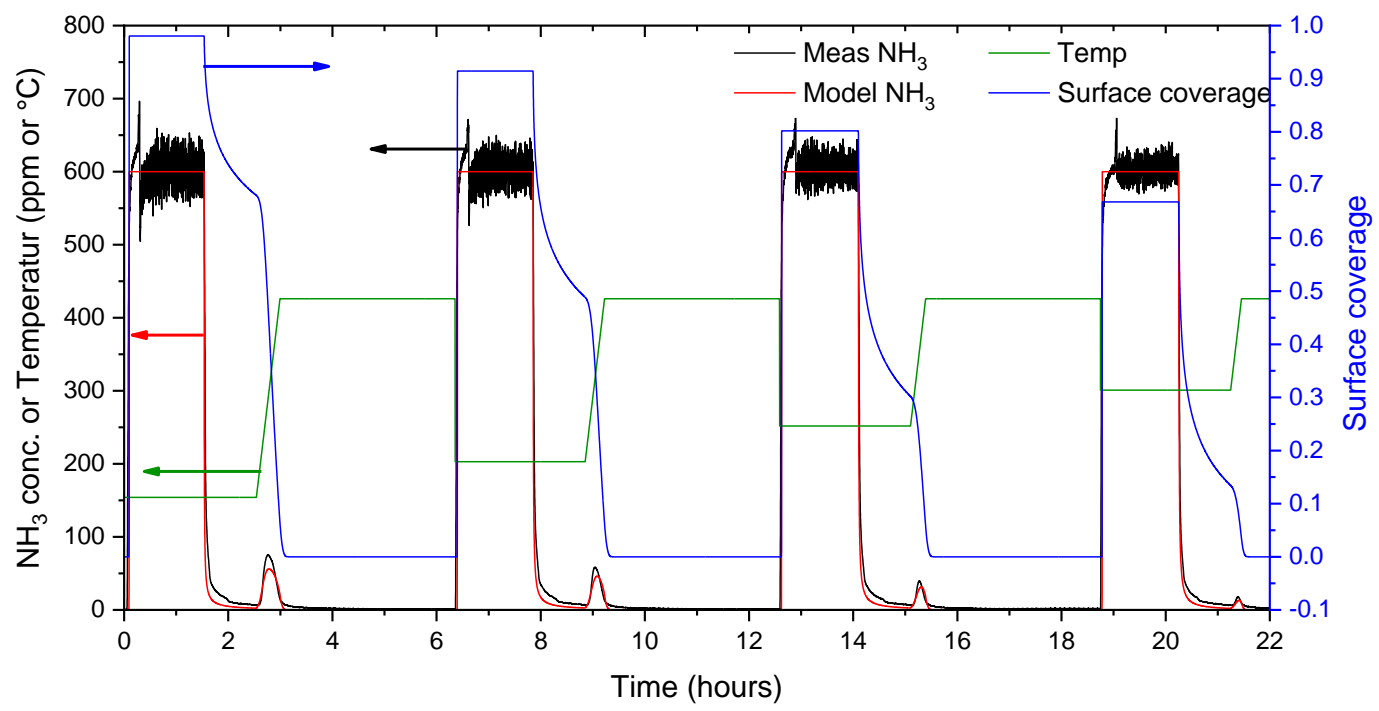

Fig. 8 Measured and predicted $\mathrm{NH}_{3}$ adsorption and desorption at 4.5 bar, using an $\mathrm{NH}_{3}$ concentration of $600 \mathrm{ppm}$, at four different temperatures $\left(150,200,250\right.$, and $\left.300^{\circ} \mathrm{C}\right)$. The model is based on the fitted parameters shown in Table 1. A zoom of the desorption peeks can be found in the supplementary material

\section{Modeling the Steady State SCR experiments using $\mathrm{NH}_{3}$ TPD kinetics}

The fitted $\mathrm{NH}_{3}$ adsorption and desorption kinetics (see Table 1), were used to model the steady state SCR experiments shown in Fig. 3. The steady state gas phase concentration of $\mathrm{NH}_{3}$ and $\mathrm{NO}$ calculated for an isothermal plug flow reactor can be written as given by Equation (15) and Equation (16), respectively.

$$
\begin{gathered}
\frac{d C_{N H 3}}{d W}=\left(r_{d}-r_{a}\right) \cdot \frac{\Omega \cdot \varepsilon}{v_{0} \cdot \rho \cdot(1-\varepsilon)} \\
\frac{d C_{N O}}{d W}=-r_{N O} \cdot \frac{\Omega \cdot \varepsilon}{v_{0} \cdot \rho \cdot(1-\varepsilon)}
\end{gathered}
$$

In which the rate of NO reduction is given by Equation (17)[46].

$$
r_{N O}=k_{N O} \cdot C_{N O} \cdot \theta_{N H 3}^{*} \cdot\left(1-\exp \left(\frac{-\theta_{N H 3}}{\theta_{N H 3}^{*}}\right)\right)
$$

The rate given by Equation (17) takes into account that only a certain fraction of the sites $\left(\theta_{N H 3}^{*}\right)$, are active in the SCR reaction. These active sites are filled up at a lower partial pressure of $\mathrm{NH}_{3}$ than the total number of sites. For example, at a total coverage of 0.5 , and with $\theta_{N H 3}^{*}=0.14$, as will be shown later, the fraction of covered active sites $\left(\theta_{N H 3}^{*}\right)$ 
is $97 \%$. The fraction of active sites is a constant that is fitted to the experimental data within a range of 0 to 1 . The NO rate constant is assumed to follow a regular Arrhenius expression written in modified form as shown in Equation (18).

$$
k(T)=k\left(T_{r e f}\right) \cdot \exp \left(\frac{-E_{A, N O}}{R} \cdot\left(\frac{1}{T}-\frac{1}{T_{r e f}}\right)\right)
$$

When the Arrhenius equation is written in the form shown in Equation (18), in which $k\left(T_{\text {ref }}\right)$ and $E_{A, N o}$ are fitted, the parameters correlates less[49]. $T_{\text {ref }}$ was chosen as $230^{\circ} \mathrm{C}$.

The steady state surface coverage of $\mathrm{NH}_{3}$ is now also a function of the NO reaction rate due to the equimolar consumption of $\mathrm{NH}_{3}$ on the surface of the catalyst by $\mathrm{NO}$, as given by Equation (19).

$$
\frac{d \theta_{N H 3}}{d t}=0=r_{a}-r_{d}-r_{N O}
$$

As shown in the online supplementary material the effectiveness factor is above 0.9 for all pressures and for temperatures below $380^{\circ} \mathrm{C}$, and hence diffusion limitations were not taken into account. Furthermore, the axial and radial dispersion are also calculated in the online supplementary material, showing that the assumption of plug flow is valid.

The three remaining unknown $\mathrm{SCR}$ related parameters, i.e., $\mathrm{k}\left(\mathrm{T}_{\mathrm{ref}}\right), \mathrm{E}_{\mathrm{A}, \mathrm{NO}}$, and $\theta_{N H 3}^{*}$, were fitted to the steady state SCR data shown in Fig. 3, using Matlab's function "Isqcurvefit" which minimizes on the residual sum of squares (RSS). The fitted parameters are shown in Table 2 together with the parameters fitted by Lietti et al.[46] at atmospheric pressure.

Table 2 The fitted SCR parameters using the Temkin $\mathrm{NH}_{3}$ adsorption and desorption parameters given in Table 1. The rate fitted by Lietti et al.[46] is based on a regular Arrhenius expression, the displayed rate constant is calculated based on the reported activation energy $(59.4 \mathrm{~kJ} / \mathrm{mol})$ and pre-exponential factor $\left(7.19 \cdot 10^{5} \mathrm{~m}^{3} / \mathrm{s} / \mathrm{mol}\right)$

\begin{tabular}{ccc}
\hline Parameters & This study & Lietti et al.[46] \\
\hline $\mathrm{k}\left(230^{\circ} \mathrm{C}\right)\left[\mathrm{m}^{3} / \mathrm{mol} / \mathrm{s}\right]$ & 2.21 & 0.48 \\
$\mathrm{E}_{\mathrm{A}, \mathrm{NO}}[\mathrm{kJ} / \mathrm{mol}]$ & 64.6 & 59.4 \\
$\theta_{N H 3}^{*}$ & 0.141 & 0.121 \\
\hline
\end{tabular}


The fitted kinetics, as shown in Table 2, are similar to those reported by Lietti et al.[46] and similar activation energies can be found for the SCR reaction in the literature, e.g. 55 $\mathrm{kJ} / \mathrm{mol}[36]$ and $67 \mathrm{~kJ} / \mathrm{mol}[50]$, however, higher activation energies are also reported, e.g. $80 \mathrm{~kJ} / \mathrm{mol}[51]$ and $94 \mathrm{~kJ} / \mathrm{mol}[42]$. Furthermore, Table 2 shows that the estimated fraction of active sites is low for both this study $\left(\theta_{N H 3}^{*}=0.14\right)$ and the study by Lietti et al.[46] $\left(\theta_{N H 3}^{*}=0.12\right)$. The low fraction of active sites, means that the rate of NO disappearance will quickly be independent of the total amount of $\mathrm{NH}_{3}$ adsorbed on the surface of the catalyst. This indicates that the active sites of the catalyst are easily covered by $\mathrm{NH}_{3}$, and that the increased adsorption observed at increased pressure adsorbs on non-active sites, most likely on the $\mathrm{TiO}_{2}$ support and to some extent the $\mathrm{WO}_{3}$ promoter. Titania is known to adsorb $\mathrm{NH}_{3}$ without having any activity in the SCR reaction, while tungsten on the other hand does exhibit SCR activity, however, the activity is in the order of 10 times below that of vanadium [46]. It is therefore expected that $\mathrm{Ti}$ and $\mathrm{W}$ mainly act as a reservoir for the $\mathrm{NH}_{3}$ storage, and that the active sites for the SCR reaction correlate to the surface coverage of vanadium as also proposed by Lietti et al.[46]. They measured the surface coverage of vanadium $\left(\theta_{v}\right)$ for a ternary catalyst to be $\theta_{N H 3}^{*}=0.12$ vs. $\theta_{v}=0.12$ and for binary catalyst $\theta_{N H 3}^{*}=0.08 v s . \theta_{v}=0.21$ and explained that the active sites was expected to be $\mathrm{V}-\mathrm{OH}$ and $\mathrm{V}=\mathrm{O}$ sites as also proposed by Dumesic et al.[52]. The reservoir adsorbed $\mathrm{NH}_{3}$ can then redistribute either through desorption-adsorption processes or through diffusion on the surface of the catalyst, which could affect the transient behavior of the catalytic system. This also explains why the increased $\mathrm{NH}_{3}$ storage on the surface of the catalyst at increased pressure (See Fig. 6), does not result in an increased $\mathrm{NO}_{\mathrm{x}}$ reduction since the active sites are already covered with $\mathrm{NH}_{3}$.

\section{Simulations Using the Fitted Temkin Kinetics}

An experiment with a constant flow rate of $600 \mathrm{NmL} /$ min containing $10 \% \mathrm{O}_{2}, 8 \% \mathrm{H}_{2} \mathrm{O}, 600$ ppm NO $\mathrm{N}_{x}$ ANR $=0.8$ in $\mathrm{N}_{2}$ was performed, and the pressure was changed from 1.4 bar to $4.4 \mathrm{bar}$, this time with the residence time as a function of the pressure, i.e. using a flow of $600 \mathrm{NmL} / \mathrm{min}$ at all pressures. All four experiments were simulated using the Temkin isotherm, using the parameters given in Table 1 and Table $\mathbf{2}$ to test how well the model fit another set of experimental data. The results are shown in Fig. $\mathbf{9}$. 


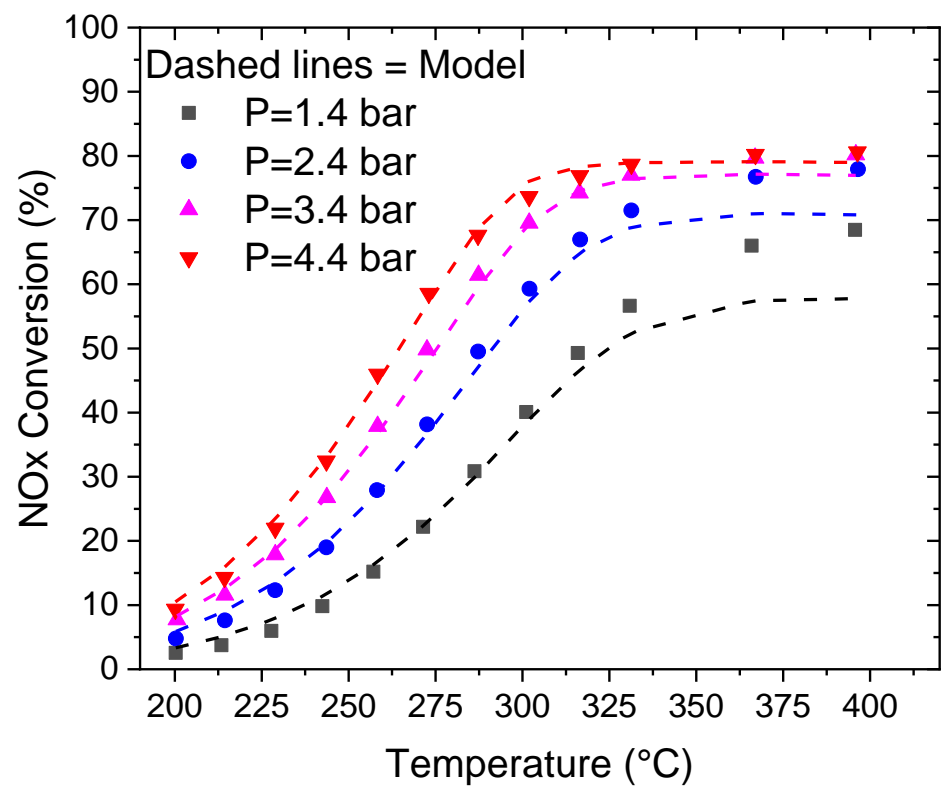

Fig. 9 Packed bed steady state SCR experiment using $20.5 \mathrm{mg}\left(\sim 1 \mathrm{wt} \% \mathrm{~V}_{2} \mathrm{O}_{5}\right) \mathrm{V}$-SCR catalyst and a total volumetric flow rate of $600 \mathrm{NmL} /$ min containing $10 \% \mathrm{O}_{2}, 8 \% \mathrm{H}_{2} \mathrm{O}, 600 \mathrm{ppm} \mathrm{NO}, \mathrm{ANR}=0.8$ in $\mathrm{N}_{2}$ and changing the pressure without changing the flow. Dashed lines are based on the Temkin parameters shown in Table 1 and Table 2

Fig. 9 shows that at temperatures below $300^{\circ} \mathrm{C}$, the model predicts the experimental data well. At this low conversion of $\mathrm{NO}_{\mathrm{x}}$, and low temperature, the NO reduction rate is not dependent on the $\mathrm{NH}_{3}$ concentration, i.e. the active sites $\left(\theta_{N H 3}^{*}\right)$, are fully covered and the model rely on the NO kinetics, which were fitted for the similar steady state experiments, and hence should predict the data. At temperatures above $300^{\circ} \mathrm{C}$, the $\mathrm{NH}_{3}$ available for the SCR reaction starts to become limiting, i.e. $\left[\theta_{N H 3}^{*} \cdot\left(1-\exp \left(\frac{-\theta_{N H 3}}{\theta_{N H 3}^{*}}\right)\right)<\right.$ $\left.\theta_{N H 3}^{*}\right]$ and the $\mathrm{NO}_{x}$ conversion becomes more and more dependent on the $\mathrm{NH}_{3}$ coverage, which was fitted to the separate ammonia TPD experiments. At 1.2 bar, the fitted Temkin isotherm, was unable to fit the observed $\mathrm{NH}_{3}$ desorption profile at an adsorption temperature of $300^{\circ} \mathrm{C}$ (Fig. 7) and therefore, at steady state $\mathrm{NO}_{x}$ reduction, this also becomes visible, due to a predicted too low overall $\mathrm{NH}_{3}$ coverage and therefore also a too low coverage on the active sites. As the pressure increases, the Temkin isotherm was observed to predict the $\mathrm{NH}_{3}$ coverage better, and as shown in Fig. 9, this is also the case in steady state $\mathrm{NO}_{\mathrm{x}}$ reduction, as expected.

\section{Full Monolith Experiment}

SCR experiments were carried out using a V-SCR catalyst $\left(\sim 1 \mathrm{wt} \% \mathrm{~V}_{2} \mathrm{O}_{5}\right)$, in the form of a monolith with an open inlet area of $223 \mathrm{~mm}^{2}$ (see Fig. 2b). The $\mathrm{NO}_{x}$ reduction measured 
across the monolith as a function of temperature for the two pressures and two ANR's are shown in Fig. 10.

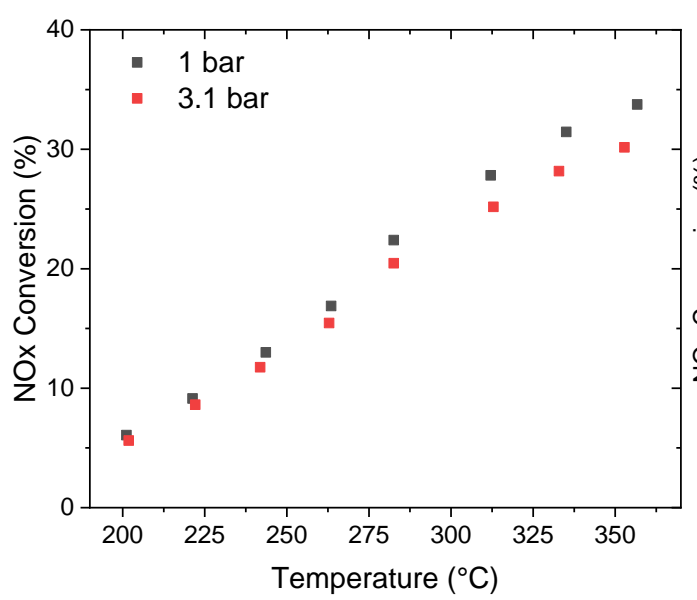

Fig. 10a ANR $=1.16$

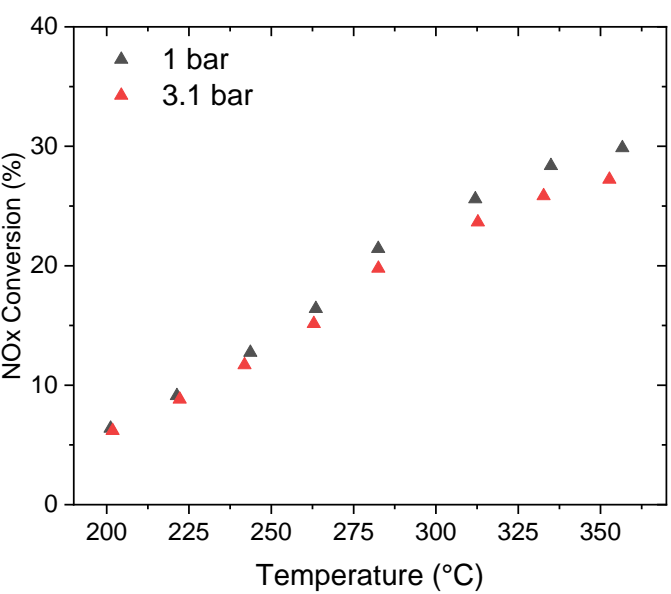

Fig. $10 \mathrm{~b}$ ANR $=0.75$

Fig. 10 Monolith experiments using a total volumetric flow rate of $4.9 \mathrm{Nm}^{3} / \mathrm{h}$ at 1 bar containing $8 \% \mathrm{O}_{2}, 5 \% \mathrm{H}_{2} \mathrm{O}, 720 \mathrm{ppm} \mathrm{NO}_{x}, \mathrm{ANR}=1.16$ (a) or ANR $=0.75$ (b) in $\mathrm{N}_{2}$. At 3.1 bar a total volumetric flow rate of $14.5 \mathrm{Nm}^{3} / \mathrm{h}$, was used, and hence the actual residence time is similar at the two pressures

Fig. 10 shows that at the low temperature of $200^{\circ} \mathrm{C}$, similar $\mathrm{NO}_{\mathrm{x}}$ conversions are observed independently of the pressure when the residence time is constant. As the temperature is increased a lower $\mathrm{NO}_{x}$ conversion is observed for the 3.1 bar experiment, which was not observed in the packed bed reactor experiments. The lower $\mathrm{NO}_{\mathrm{x}}$ conversion at elevated pressures becomes visible around $250^{\circ} \mathrm{C}$ and more pronounced as the temperature is increased. At a temperature of approximately $250^{\circ} \mathrm{C}$ the SCR reaction across a monolith starts to become influenced by external and internal diffusion limitations and as the temperature is increased these limitations becomes more pronounced[24]. The increased diffusion limitations at increased pressure is linked to the inverse proportionality between pressure and the binary diffusion coefficient which will limit the SCR reaction. The same trends were reported by Kröcher et al.[35] for a similar monolith experiment.

To simulate the monolith experiments, including the increased diffusion limitations observed at increased pressure, we used the single channel monolith model developed by Olsen[53]. The model is a 1D-1D single channel monolith model, which calculates the concentration profiles of $\mathrm{NH}_{3}$ and $\mathrm{NO}$ both in the radial direction within the catalytic wall and in axial direction. The model was developed to simulate the deactivation of SCR monoliths caused by $\mathrm{KCl}$ deposition, however, in this study only the SCR reaction part of 
the model is used. The model is based on Eley-Rideal kinetics (see Eq. (6)), and therefore, the steady state SCR experiments from the packed bed reactor (Fig. 3) were re-fitted under the assumption of a plug flow reactor, and following the Eley-Rideal mechanism as shown in Equation(20).

$$
\frac{d C_{N O}}{d W}=\frac{k_{N O}^{\prime} \cdot C_{N O}}{v_{0}} \cdot \frac{K_{N H 3} \cdot C_{N H 3}}{1+K_{N H 3} \cdot C_{N H 3}}
$$

Both the $\mathrm{NO}$ rate constant and the $\mathrm{NH}_{3}$ adsorption equilibrium constant were assumed to follow an Arrhenius equation. The fitting resulted parameters are shown in Table $\mathbf{3}$ and in Fig. 11 a plot similar to Fig. 9 is shown, but now also displaying how well the Eley-Rideal kinetics fit the experimental data.

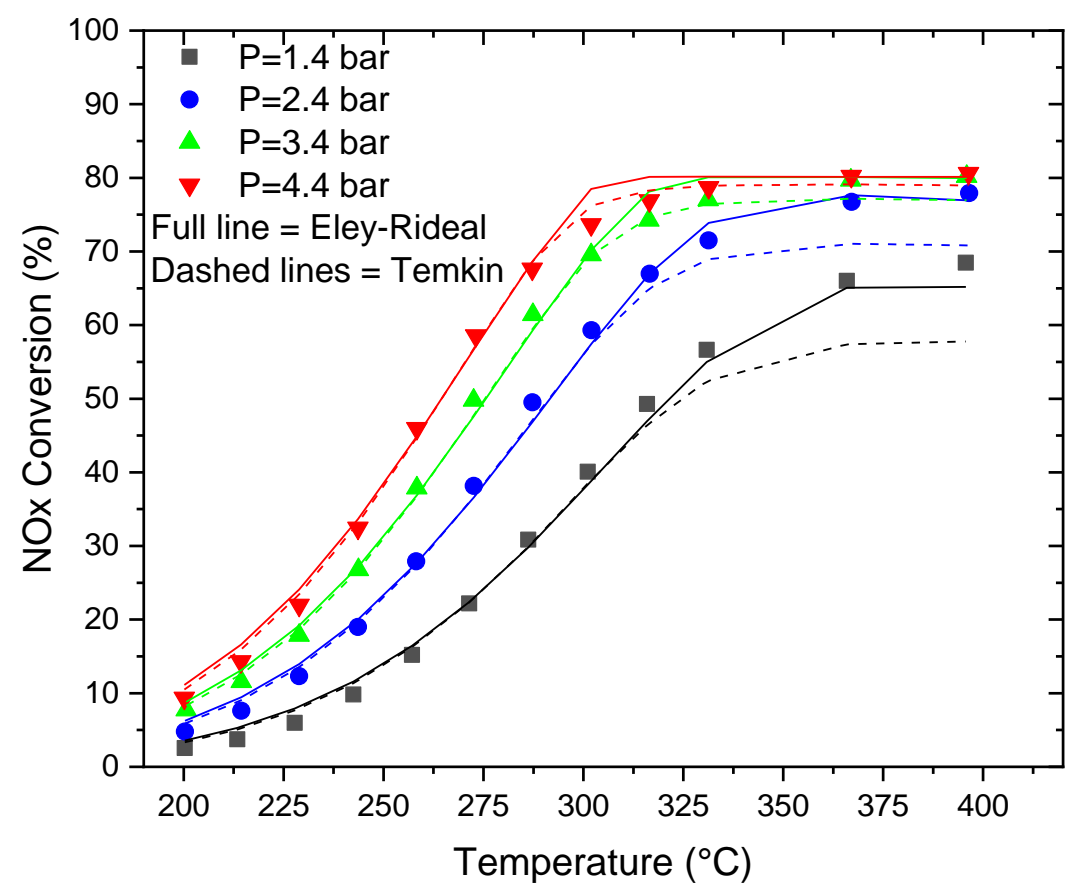

Fig. 11 Steady state SCR experiment using $20.5 \mathrm{mg}\left(\sim 1 \mathrm{wt} \% \mathrm{~V}_{2} \mathrm{O}_{5}\right)$ V-SCR catalyst and a total volumetric flow rate of $600 \mathrm{NmL} /$ min containing $10 \% \mathrm{O}_{2}, 8 \% \mathrm{H}_{2} \mathrm{O}, 600 \mathrm{ppm} \mathrm{NO}, \mathrm{ANR}=0.8$ in $\mathrm{N}_{2}$ and changing the pressure without changing the flow. Dashed lines are based on the Temkin parameters shown in Table 1 and Table 2, and full lines are based on Eley-Rideal kinetics using the parameters shown in Table 3

In Table 3, the pre-exponential factor and the activation energy for the NO rate constant is shown together with the pre-exponential factor and the adsorption enthalpy of $\mathrm{NH}_{3}$, both of which are used to calculate the rate of NO reduction in the monolith model. 
Table 3 The fitted Eley-Rideal parameters using the packed bed experimental data presented in Fig. 3 and the fitted parameters reported by Koebel \& Elsener [54]. The NO rate constant, and the $\mathrm{NH}_{3}$ equilibrium constant are both assumed to follow an Arrhenius equation

\begin{tabular}{ccc}
\hline Parameters & This study & Koebel \& Elsener[54] \\
\hline $\mathrm{k}^{\prime}{ }_{\mathrm{NO}}\left(\mathrm{T}_{230}\right)\left[\mathrm{m}^{3} / \mathrm{s} / \mathrm{kg}\right]$ & 0.0588 & 0.014 \\
$\mathrm{E}_{\mathrm{A}, \mathrm{NO}}[\mathrm{kJ} / \mathrm{mol}]$ & 62.5 & 74.7 \\
$\mathrm{~K}_{\mathrm{NH} 3,0}\left[\mathrm{~Pa}^{-1}\right]$ & $24.1 \cdot 10^{-12}$ & $3 \cdot 10^{-12}$ \\
$\Delta \mathrm{H}_{\mathrm{NH} 3, \mathrm{ad}}[\mathrm{kJ} / \mathrm{mol}]$ & -114.6 & -137 \\
\hline
\end{tabular}

When modelling reactions in a monolith, a correlation for the external mass transfer coefficient for developing laminar flow is often applied, such as that proposed by Tronconi et al.[42,55], based upon the work of Shah et al.[56] and London et al.[57] as shown in Equation (21).

$$
\begin{gathered}
S h=S h_{\infty}+8.827 \cdot\left(1000 Z^{*}\right)^{-0.545} \exp \left(-48.2 Z^{*}\right) \\
Z^{*}=\frac{Z \cdot D_{\mathrm{AB}}}{U \cdot d_{h}^{2}}
\end{gathered}
$$

Here $S h_{\infty}$ is the asymptotic Sherwood number, which depends on the channel geometry, and $Z^{*}$ is the dimensionless axial coordinate given by Equation (22), in which $z$ is the axial coordinate, $D_{A B}$ is the binary diffusion coefficient, $U$ is the linear velocity and $d_{h}$ is the hydraulic diameter. Equation (21) was found to give poor agreement with the experimental results, predicting a too low $\mathrm{NO}_{x}$ conversion as shown for 3.1 bar in Fig. 12 . Since the powder used in the packed bed experiments was obtained from a similar monolith, this discrepancy was attributed to a too low mass transfer coefficient. It was therefore considered that the assumption of a developing laminar flow was not applicable to this experiment using a short monolith $(10 \mathrm{~cm})$ and a high flow rate. The Reynolds number within the monolith channel was calculated to be approximately 1000 at 1 bar and 3000 at 3 bar. Therefore, a mean mass transfer coefficient for the channel was instead calculated based upon laminar flow in tubes, as given by Equation (23)[47] at 1 bar. At high pressure however, this correlation, valid for laminar flow, was found to be inadequate. Since the Reynolds number is in the intermediate range between turbulent and laminar flow, a turbulent model for flow in tubes (Equation (24)[47]) was tested. An estimate of the roughness of the catalyst channel surface of $0.03 \mathrm{~mm}$ was found to result 
in a friction factor (f) of approximately 0.012 , which was calculated based upon the Churchill equations[58], which gave a good fit for the NOx conversion.

$$
\begin{gathered}
S h=1.86 \cdot G z^{1 / 3}=1.86 \cdot\left(R e \cdot S c \cdot \frac{d_{h}}{L}\right)^{1 / 3} \\
S h=0.5 \cdot f \cdot R e \cdot S c^{1 / 3}
\end{gathered}
$$

Here $R e$ is Reynolds number, $S c$ is Schmidt's number, $d_{h}$ is the hydraulic diameter, and $L$ is the length of the monolith. The model prediction using these expressions for external mass transfer limitations are shown in Fig. 12.

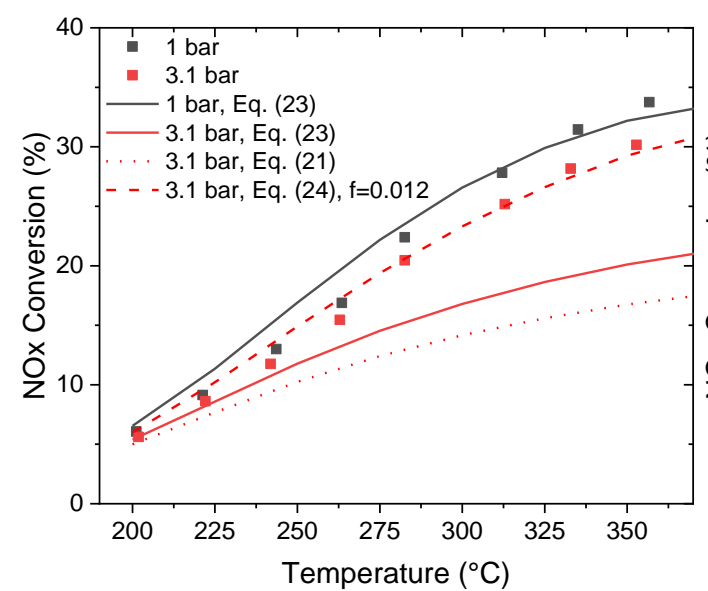

Fig. 12a $A N R=1.16$

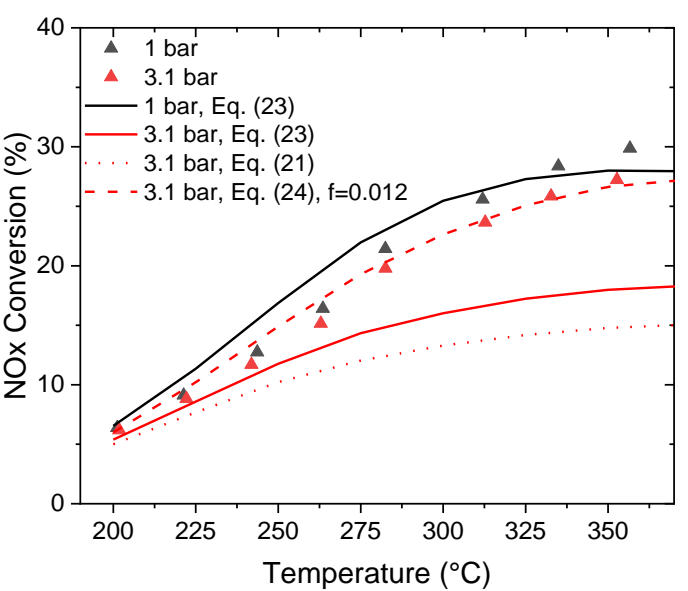

Fig. 12b ANR $=0.75$

Fig. 12 The monolith experiment also shown in Fig. 10. The model developed by Olsen et al.[53] was used to predict the experimental data, using the PBR kinetics as shown in Table 3. The external mass transfer coefficient was calculated assuming pure laminar flow at 1 bar (Equation (23)) and as both developing laminar flow (Equation (21)), laminar flow (Equation (23)), and turbulent flow at 3.1 bar (Equation (24))

Fig. 12 shows that the use of developing laminar flow results in a large error as high as 15 $\%$ points in the calculated $\mathrm{NO}_{x}$ conversion compared to the observed $\mathrm{NO}_{x}$ reduction. The more general correlations as given in Equation (23) at a Reynolds number of 1000 (1 bar) and Equation (24) at a Reynolds number of 3000 (3.1 bar), were found to give better agreement. The model predicts a drop in $\mathrm{NO}_{\mathrm{x}}$ conversion when the pressure is increased due to increased diffusion limitations. Regular length, full open monoliths should be tested in a future study, to see how well mass transfer correlations for developing laminar flow predicts the external mass transfer at increased pressure when a more typical velocity $3-5 \mathrm{~m} / \mathrm{s}$ and length of $0.5 \mathrm{~m}$ is used. From this study, it is concluded that at an 
increased pressure, when the residence time is kept constant, a decrease in $\mathrm{NO}_{x}$ reduction efficiency is observed, due to increasing external and internal mass transfer limitations, as also discussed by Kröcher et al.[35].

It should be noted that the drop in $\mathrm{NO}_{\mathrm{x}}$ reduction is only observed because the residence time is kept constant with variations in the pressure. If an SCR reactor was installed on a ship, the residence time would increase with increasing pressure, and the total effect of increasing pressure becomes positive. Kröcher et al.[35] measured that to achieve 70\% $\mathrm{NO}_{x}$ reduction at $350^{\circ} \mathrm{C}$ and having an $\mathrm{NH}_{3}$ slip of $10 \mathrm{ppm}$, the volume of a $87 \mathrm{cpsi}$ catalyst could be reduced from $100 \%$ at 1 bar, to $80 \%$ at 2 bar and $70 \%$ at 4 bar, which shows that in total a positive effect of pressure is obtained. If no diffusion limitations had been present the catalyst volume could have been reduced to $50 \%$ and $25 \%$ at 2 and 4 bar respectively.

\section{Conclusion}

The following conclusions can be drawn from this study of SCR of $\mathrm{NO}_{x}$ at pressures up to 5 bar for a $\sim 1$ wt $\% \mathrm{~V}_{2} \mathrm{O}_{5} / 10$ wt $\% \mathrm{WO}_{3} / \mathrm{TiO}_{2}$ catalyst.

- The measured $\mathrm{NO}_{x}$ conversion was independent of the pressure in the range 1.2-4.8 bar over a packed bed reactor with catalyst particles in the sieve range 150-300 microns with no diffusion limitations, when the residence time was kept constant. This shows that the kinetics are independent of pressure up to 5 bar.

- A transient model for $\mathrm{NH}_{3}$ adsorption/desorption on the catalyst based on a Temkin isotherm, were fitted to the experimental data. The data indicates that only a certain fraction of the total sites onto which $\mathrm{NH}_{3}$ adsorbs are truly active in the SCR reaction. This fraction was found to be about $14 \%$. It was further found that these sites fill up at lower $\mathrm{NH}_{3}$ partial pressure compared to all sites.

- The adsorption of $\mathrm{NH}_{3}$ on the catalyst was found to increase with increasing pressure and decrease with increasing temperature. The increased adsorption at increased pressure was found to be on non-active sites, and the rate of $\mathrm{NO}_{\mathrm{x}}$ reduction was therefore not promoted by the increased adsorption of $\mathrm{NH}_{3}$.

- Experiments using a monolith showed that at an increased pressure of 3.1 bar, keeping the gas residence time constant relative to at 1 bar, a decrease in $\mathrm{NO}_{\mathrm{x}}$ reduction was observed at temperatures above $250^{\circ} \mathrm{C}$. This decrease was attributed 
to a decrease in the binary diffusion coefficient, which is inversely proportional to the pressure. The drop in $\mathrm{NO}_{x}$ conversion was confirmed by a 1D-1D model.

- Estimation of the external mass transfer coefficient using correlations for developing laminar flow lead to poor agreement with the experimental data, and instead a correlation for turbulent flow was required, probably due to the high velocity (10-13 $\mathrm{m} / \mathrm{s}$ ) used in this work.

- This study has shown that the intrinsic kinetics of the SCR reaction is independent on pressure, and so kinetics determined at 1 bar can be used for design of SCR reactors also at elevated pressures, such as upstream of the turbocharger on a two-stroke marine diesel engine. The increased pressure does affect the binary diffusion coefficient, and hence increased mass transfer limitations will take effect on monolithic catalysts at temperatures above approximately $250^{\circ} \mathrm{C}$.

\section{Acknowledgment}

This work is part of the Danish societal partnership, Blue INNOship and partly funded by Innovation Fund Denmark (IFD) under File No: 155-2014-10 and the Danish Maritime Fund. The authors gratefully acknowledge the funding support.

\section{Compliance with Ethical standards}

On behalf of all authors, the corresponding author states that there is no conflict of interest.

\section{Abbreviations}

ABS

ANR

AS

CPSI

CSTR

EGR

IMO

LNG
Ammonium bisulfate

Ammonia to $\mathrm{NO}_{x}$ ratio

Ammonium sulfate

Channels pr. square inch

Continuous stirred tank reactor

Exhaust gas recirculation

International maritime organization

Liquid natural gas 
NECA

$\mathrm{NO}_{x}$

PBR

RSS

SCR

SECA

$\mathrm{SO}_{\mathrm{x}}$

V-SCR

\section{Symbols}

$\alpha$

$C_{N H 3}$

$d_{\text {particle }}$

Dreactor

$D_{A B}$

$d_{h}$

$\varepsilon$

$E_{a}$

$E_{d}^{0}$

f

$\mathrm{Gz}$

$k_{N O}$

$k^{\prime}{ }_{N O}$

$k_{a}^{0}$
$\mathrm{NO}_{x}$ emission control area

Nitrogen oxides, the sum of $\mathrm{NO}$ and $\mathrm{NO}_{2}$

Packed bed reactor

Residual sum of squares

Selective catalytic reduction

SOx emission control area

Sulfur oxides, the sum of $\mathrm{SO}_{2}, \mathrm{SO}_{3}$, and $\mathrm{H}_{2} \mathrm{SO}_{4}$

Vanadium based SCR catalyst

Temkin kinetics parameter [-]

$\mathrm{NH}_{3}$ concentration $\left[\mathrm{mol} / \mathrm{m}^{3}\right.$ ]

Catalyst particle diameter $[\mathrm{m}]$

Reactor tube diameter [m]

binary diffusion coefficient $\left[\mathrm{m} / \mathrm{s}^{2}\right]$

hydraulic diameter $[\mathrm{m}]$

porosity [-]

Activation energy of the adsorption process of $\mathrm{NH}_{3}$ $[\mathrm{J} / \mathrm{mol}]$

Activation energy for the desorption process of $\mathrm{NH}_{3}$ $[\mathrm{J} / \mathrm{mol}]$

Friction factor [-]

Graetz dimensional number [-]

NO first order rate constant [1/s]

Mass based NO first order rate constant $\left[\mathrm{m}^{3} / \mathrm{s} / \mathrm{kg}\right]$

Pre-exponential factor of the adsorption process of $\mathrm{NH}_{3}\left[\mathrm{~m}^{3} / \mathrm{mol} / \mathrm{s}\right]$ 


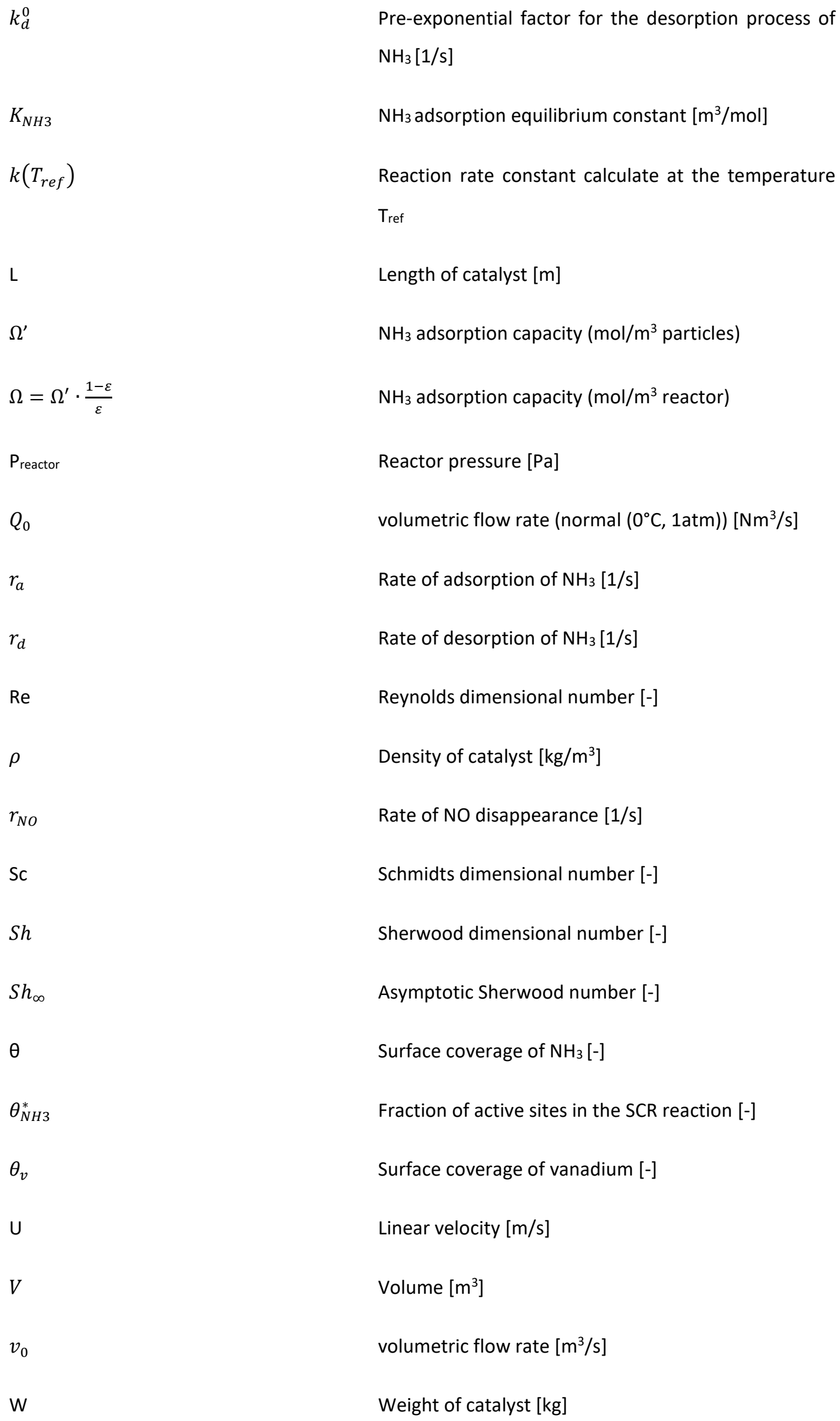




$\begin{array}{ll}\text { Ymeas } & \begin{array}{l}\text { Vectors containing the measured gas phase mole } \\ \text { fraction }[\mathrm{ppm}]\end{array} \\ \text { Ymodel } & \begin{array}{l}\text { Vectors containing the modeled gas phase mole } \\ \text { fraction }[\mathrm{ppm}]\end{array} \\ z & \text { Axial coordinate }[\mathrm{m}] \\ Z^{*} & \text { Dimensionless axial coordinate }[-]\end{array}$

\section{References}

[1] Å.M. Hallquist, E. Fridell, J. Westerlund, M. Hallquist, Onboard Measurements of Nanoparticles from a SCR-Equipped Marine Diesel Engine, Environ. Sci. \& Technol. 47 (2013) 773-780. doi:10.1021/es302712a.

[2] Man Diesel \& Turbo, Exhaust gas emission control today and tomorrow. http://marine.man.eu/docs/librariesprovider6/technical-papers/exhaust-gas-emissioncontrol-today-and-tomorrow.pdf?sfvrsn=22 (accessed September 10, 2015).

[3] M.I. Lamas, C.G. Rodríguez, Emissions from Marine Engines and NOx Reduction Methods, J. Marit. Res. 9 (2012) 77-81.

[4] J. Briggs, J. Mccarney, Field experience of Marine SCR, in: CIMAC Congr., 2013.

[5] Y. Niki, K. Hirata, T. Kishi, T. Inaba, M. Takagi, T. Fukuda, T. Nagai, E. Muraoka, SCR system for NOx reduction of Medium Speed Marine Diesel Engine, in: CIMAC Congr., 2010: p. 12.

[6] G. Lövblad, E. Fridell, Experiences from use of some techniques to reduce emissions from ships, Göteborg, 2006. http://cleantech.cnss.no/wp-content/uploads/ 2011/09/2006Lovblad-and-Fridell-Experiences-from-use-of-some-techniques-to-reduce-emissionsfrom-ships.pdf.

[7] M. Magnusson, E. Fridell, H.H. Ingelsten, The influence of sulfur dioxide and water on the performance of a marine SCR catalyst, Appl. Catal. B Environ. 111-112 (2012) 20-26. doi:10.1016/j.apcatb.2011.09.010.

[8] C. Österman, M. Magnusson, A systemic review of shipboard SCR installations in practice, WMU J. Marit. Aff. 12 (2013) 63-85. doi:10.1007/s13437-012-0034-1.

[9] K. Lehtoranta, H. Vesala, P. Koponen, S. Korhonen, Selective Catalytic Reduction Operation with Heavy Fuel Oil: NOx, NH3, and Particle Emissions, Environ. Sci. \& Technol. 49 (2015) 
4735-4741. doi:10.1021/es506185x.

[10] Det Norske Veritas (DNV), Marpol 73/78 Annex VI, (2009). http://hulpinnood.nl/wpcontent/uploads/2015/03/BIJLAGE3_Marpol-annex-VI.pdf (accessed May 9, 2016).

[11] IMO, The 2020 Global Sulfur http://www.imo.org/en/MediaCentre/HotTopics/GHG/Documents/FAQ_2020_English.pd f (accessed October 12, 2017).

[12] IMO, Emission Control Areas designated under MARPOL Annex VI, (2018). http://www.imo.org/en/OurWork/Environment/PollutionPrevention/AirPollution/Pages/ Emission-Control-Areas-(ECAs)-designated-under-regulation-13-of-MARPOL-Annex-VI(NOx-emission-control).aspx (accessed January 12, 2019).

[13] K. Mollenhauer, H. Tschöke, Handbook of Diesel Engines, Springer Berlin Heidelberg, Berlin, Heidelberg, 2010. doi:10.1007/978-3-540-89083-6.

[14] S.R. Turns, An introduction to combustion : concepts and applications, McGraw-Hill, 2012.

[15] P. Forzatti, L. Lietti, Recent Advances in DeNOxing Catalysis for Stationary Applications, Heterog. Chem. Rev. 3 (1996) 33-51.

[16] M. Koebel, M. Elsener, G. Madia, Recent Advances in the Development of Urea-SCR for Automotive Applications, Sae Tech. Pap. (2001). doi:10.4271/2001-01-3625.

[17] P. Blakeman, K. Arnby, P. Marsh, C. Newman, G. Smedler, Optimization of an SCR Catalyst System to Meet EUIV Heavy Duty Diesel Legislation, SAE Tech. Pap. 2 (2008). doi:10.4271/2008-01-1542.

[18] B. Guan, R. Zhan, H. Lin, Z. Huang, Review of state of the art technologies of selective catalytic reduction of NOx from diesel engine exhaust, Appl. Therm. Eng. 66 (2014) 395414. doi:10.1016/j.applthermaleng.2014.02.021.

[19] O. Kröcher, Aspects of catalyst development for mobile urea-SCR systems - From VanadiaTitania catalysts to metal-exchanged zeolites, in: Stud. Surf. Sci. Catal., Elsevier, 2007: pp. 261-289. doi:10.1016/S0167-2991(07)80210-2.

[20] Man Diesel \& Turbo, Tier III Two-Stroke Technology, (2012). http://marine.man.eu/docs/librariesprovider6/technical-papers/tier-iii-two-stroketechnology.pdf?sfvrsn=12 (accessed September 10, 2015).

[21] IMO, IMO MEPC 66/6/15, (2014). http://www.worldshipping.org/industryissues/environment/air-emissions/MEPC_66-6-15_-

_Comments_concerning_potential_amendments_to_the_effective___.pdf (accessed 
November 20, 2017).

[22] H. Bosch, F. Janssen, Preface, Catal. Today. 2 (1988) v. doi:10.1016/0920-5861(88)800014.

[23] G. Centi, S. Perathoner, Chapter 1 Introduction: State of the art in the development of catalytic processes for the selective catalytic reduction of NOx into N2, in: Stud. Surf. Sci. Catal., 2007: pp. 1-23. doi:10.1016/S0167-2991(07)80202-3.

[24] P. Gabrielsson, H.G. Pedersen, Flue Gas From Staionary Sources, in: G. Ertl, H. Knözinger, F. Schüth, J. Weitkamp (Eds.), Handb. Heterog. Catal., Wiley-VCH, 2008: pp. 2345-2385. http://findit.dtu.dk/en/catalog/2342172429 (accessed March 29, 2017).

[25] I. Nova, E. Tronconi, Urea-SCR Technology for deNOx After Treatment of Diesel Exhausts, Springer, 2014. doi:10.1007/978-1-4899-8071-7.

[26] Marine Fuels 2020. https://www.marinefuels2020.com/marine-fuels/background/ (accessed April 6, 2019).

[27] CIMAC Working Group 8, CIMAC Guideline: Cold Corrosion in Marine Two Stroke, CIMAC Guidel. $1-36$. https://cimac.com/cms/upload/Publication_Press/WG_Publications/CIMAC_WG8_Guidel ine_2017_Two_Stroke_Engine_Cold_Corrosion.pdf.

[28] C. Orsenigo, A. Beretta, P. Forzatti, J. Svachula, E. Tronconi, F. Bregani, A. Baldacci, Theoretical and experimental study of the interaction between NOx reduction and $\mathrm{SO} 2$ oxidation over DeNOx-SCR catalysts, Catal. Today. 27 (1996) 15-21. doi:10.1016/09205861(95)00168-9.

[29] E. Tronconi, A. Cavanna, C. Orsenigo, P. Forzatti, Transient Kinetics of SO2 Oxidation Over SCR-DeNOx Monolith Catalysts, Ind. \& Eng. Chem. Res. 38 (1999) 2593-2598. doi:10.1021/ie980673e.

[30] L. Muzio, S. Bogseth, R. Himes, Y.-C. Chien, D. Dunn-Rankin, Ammonium bisulfate formation and reduced load SCR operation, Fuel. 206 (2017) 180-189. doi:10.1016/j.fuel.2017.05.081.

[31] J.M. Burke, K.L. Johnson, Ammonium sulfate and bisulfate formation in air preheaters (Project Summary), 1982. http://nepis.epa.gov/Exe/ZyPURL.cgi?Dockey=2000TU1N.txt.

[32] S. Matsuda, T. Kamo, A. Kato, F. Nakajima, T. Kumura, H. Kuroda, Deposition of ammonium bisulfate in the selective catalytic reduction of nitrogen oxides with ammonia, Ind. \& Eng. Chem. Prod. Res. Dev. 21 (1982) 48-52. doi:10.1021/i300005a009. 
[33] T. Fujibayashi, S. Baba, H. Tanaka, Development of Marine SCR System for Large Two-stroke Diesel Engines Complying with IMO NO x Tier III, in: CIMAC Congr., 2013.

[34] R. Bank, B. Buchholz, H. Harndorf, R. Rabe, U. Etzien, High-Pressure SCR at Large Diesel Engines for Reliable NOx -Reduction and Compliance with IMO Tier III Standards, in: CIMAC Congr., 2013.

[35] O. Kröcher, M. Elsener, M.-R. Bothien, W. Dölling, Pre-Turbo SCR - Influence of Pressure on NOx Reduction, MTZ Worldw. 75 (2014) 46-51. doi:10.1007/s38313-014-0140-x.

[36] T. Rammelt, B. Torkashvand, C. Hauck, J. Böhm, R. Gläser, O. Deutschmann, Nitric Oxide Reduction of Heavy-Duty Diesel Off-Gas by NH3-SCR in Front of the Turbocharger, Emiss. Control Sci. Technol. 3 (2017) 275-288. doi:10.1007/s40825-017-0078-y.

[37] K. Sandelin, D. Peitz, SCR under pressure - pre-turbocharger NOx abatement for marine 2stroke diesel engines, in: CIMAC Congr., 2016.

[38] W. Schüttenhelm, C. Günther, R. Jürgens, high pressure SCR for large two-stroke engines and comparison to conventional SCR high dust applications, VGB Powertech. 8 (2017) 5862.

[39] R.B. Bird, W.E. Stewart, E.N. Lightfoot, Transport phenomena, J. Wiley, 2007.

[40] S.R. Christensen, B.B. Hansen, K. Johansen, K.H. Pedersen, J.R. Thøgersen, A.D. Jensen, SO2 Oxidation Across Marine V2O5-WO3-TiO2 SCR Catalysts: a Study at Elevated Pressure for Preturbine SCR Configuration, Emiss. Control Sci. Technol. (2018). doi:10.1007/s40825018-0092-8.

[41] M. Koebel, G. Madia, M. Elsener, Selective catalytic reduction of NO and NO2 at low temperatures, Catal. Today. 73 (2002) 239-247. doi:10.1016/S0920-5861(02)00006-8.

[42] E. Tronconi, P. Forzatti, J.P. Gomez Martin, S. Mallogi, Selective catalytic removal of NOx: a mathematical model for design of catalyst and reactor, Chem. Eng. Sci. 47 (1992) 24012406. doi:10.1016/0009-2509(92)87067-Z.

[43] I. Nova, L. Lietti, A. Beretta, P. Forzatti, Study of the sintering of a deNOx commercial catalyst, Stud. Surf. Sci. Catal. 139 (2001) 149-156. doi:10.1016/S0167-2991(01)80192-0.

[44] J.A. Dumesic, N.-Y. Topsøe, H. Topsøe, Y. Chen, T. Slabiak, Kinetics of Selective Catalytic Reduction of Nitric Oxide by Ammonia over Vanadia/Titania, J. Catal. 163 (1996) 409-417. doi:10.1006/jcat.1996.0342.

[45] H. Tsukahara, T. Ishida, M. Mayumi, Gas-Phase Oxidation of Nitric Oxide: Chemical Kinetics and Rate Constant, Nitric Oxide. 3 (1999) 191-198. doi:10.1006/niox.1999.0232. 
[46] L. Lietti, I. Nova, S. Camurri, E. Tronconi, P. Forzatti, Dynamics of the SCR-DeNOx reaction by the transient-response method, AIChE J. 43 (1997) 2559-2570. doi:10.1002/aic.690431017.

[47] O. Levenspiel, The chemical reactor omnibook, Distributed by OSU Book Stores, 1989.

[48] A.S. Pushnov, Calculation of average bed porosity, Chem. Pet. Eng. 42 (2006) 14-17. doi:10.1007/s10556-006-0045-x.

[49] J.B. Rawlings, J.G. Ekerdt, Chemical reactor analysis and design fundamentals, 2. Edition, Nob Hill Pub, 2002.

[50] P. Forzatti, I. Nova, A. Beretta, Catalytic properties in deNOx and SO2-SO3 reactions, Catal. Today. 56 (2000) 431-441. doi:10.1016/S0920-5861(99)00302-8.

[51] J.W. Beeckman, L.L. Hegedus, Design of monolith catalysts for power plant NOx emission control, Ind. \& Eng. Chem. Res. 30 (1991) 969-978. doi:10.1021/ie00053a020.

[52] J.A. Dumesic, N.-Y. Topsoe, T. Slabiak, P. Morsing, B.S. Clausen, E. Törqvist, H. Topsoe, Microiunetic Analysis of the Selective Catalytic Reduction (SCR) of Nitric Oxide Over Vanadia/Titania-Based Catalysts, in: 1993: pp. 1325-1337. doi:10.1016/S01672991(08)64454-7.

[53] B.K. Olsen, F. Castellino, A.D. Jensen, Modeling Deactivation of Catalysts for Selective Catalytic Reduction of NO x by KCl Aerosols, Ind. \& Eng. Chem. Res. 56 (2017) 13020-13033. doi:10.1021/acs.iecr.7b01239.

[54] M. Koebel, M. Elsener, Selective Catalytic Reduction of NO over Commercial DeNOx Catalysts: Comparison of the Measured and Calculated Performance, Ind. \& Eng. Chem. Res. 37 (1998) 327-335. doi:10.1021/ie970569h.

[55] E. Tronconi, P. Forzatti, Adequacy of lumped parameter models for SCR reactors with monolith structure, AIChE J. 38 (1992) 201-210. doi:10.1002/aic.690380205.

[56] R.K. Shah, A.L. London, Laminar Flow Forced Convection in Ducts, 1978.

[57] H. Tratz, U. Grigull, Thermischer Einlauf in Ausgebildeter Laminarer Rohrströmung, Int. J. Heat Mass Transf. 8 (1965) 669-678.

[58] K.H. Clement, P. Fangel, A.D. Jensen, K. Thomsen, Kemiske enhedsoperationer, Polyteknisk Forlag, 2004. 